\title{
SíNTESIS SENTENCIA DEL TRIBUNAL CONSTITUCIONAL ROL No 740/2008, RESPECTO A LA DENOMINADA "PÍlDORA DEL dÍA DESPUÉS"*
}

\author{
EMILIO PFEFFER URQUIAGA ${ }^{* *}$
}

\section{VOTO DE MAYORÍA}

Se requiere por 36 Diputados la inconstitucionalidad de "todo o parte" del D.S. No 48, de Salud, que aprueba las "Normas Nacionales sobre Regulación de la Fertilidad” (D.O., 3 febrero 2007).

\section{Incumplimiento de requisitos de admisibilidad}

No se admite a tramitación el requerimiento por carecer de la "claridad y precisión suficientes" para que el Tribunal "pueda entrar a conocer del asunto". Lo solicitado fue excluir de la norma y, por ende, prohibir por inconstitucional todos los métodos cuyo mecanismo de acción sea, entre otros, "el de la alteración endometrial, por ser abortivos "y por tanto contrarios a la Ley Fundamental..., sin que el libelo explicite "cuáles son los métodos a que se refieren y de qué forma vulnerarían la Constitución"; luego, porque "tampoco se especifican los preceptos de dicho cuerpo regulatorio que se consideran contrarios a la Carta Fundamental y respecto de los cuales se solicita la declaración" de inconstitucionalidad; $y$, finalmente, por existir una falta de armonía en las peticiones, ya que se pide la inconstitucionalidad de "todo o parte" del decreto supremo, para luego limitar la pretensión solo a algunos "aspectos de la normativa".

La falta de claridad y precisión entre la parte argumentativa del requerimiento y su petitorio o conclusión, impide entrar a conocer del asunto en relación a las objeciones que no aparecen debidamente fundadas.

Al subsanar los defectos los requirentes renuncian a la declaración de inconstitucionalidad de la totalidad del acto administrativo reglamentario

Se deja constancia que debido a la extensión del fallo en comento, no se acompańará, como es habitual, el texto íntegro de la sentencia. En este contexto, el Comité Editorial de la RDUCN ha estimado que la sistematización que se presenta, describe en lo sustancial el texto original, supliendo de esta forma tal omisión.

Profesor de Derecho Político y Constitucional en la Universidad Diego Portales, Universidad Central y Universidad del Desarrollo (Chile). Correo electrónico: emiliopfeffer@pfeffer.cl

Fecha de recepción: 29 de mayo de 2008.

Fecha de aprobación: 9 de junio de 2008. 
y dirigen su acción, específicamente, a la impugnación de la sección C, "Tecnología Anticonceptiva", particularmente a los puntos 3.3, "Anticoncepción Hormonal de Emergencia"; 4, "Anticoncepción no Hormonal", 4.1.1 "Dispositivos Intrauterinos", como también a la consejería a adolescentes que se da en el marco de confidencialidad sin consentimiento ni conocimiento de los padres, normativa desarrollada en la sección $\mathrm{D}$, bajo el título "Anticoncepción en Población Específica", en el punto 1 "Anticoncepción en Adolescentes".

\section{Alegaciones de previo y especial pronunciamiento}

El Ejecutivo plantea que: a) Se impugna una cuestión de hecho ajena a la competencia del Tribunal; b) La oportunidad para evaluar si un medicamento puede afectar los derechos de las personas se presenta cuando aquel se registra; c) Se ha solicitado al Tribunal efectuar juicios de mérito.

\section{Normas nacionales sobre regulación de la fertilidad deben abor- darse por un decreto supremo}

El Tribunal, aplicando el "principio de primacía de la realidad por sobre el nominalismo", sostuvo que la norma impugnada (Rol No 591) -una resolución ministerial- tenía las características propias de un decreto supremo, por lo que al no haber sido aprobada con las formalidades propias de esa clase de acto administrativo era inconstitucional.

\section{Requerimiento plantea una cuestión de hecho ajena a las potesta- des del Tribunal}

El control abstracto de constitucionalidad que le corresponde, en ejercicio de esta atribución ( $N^{\circ} 16$, art. 93), se ha de realizar con prescindencia de la aplicación de las normas a casos concretos o particulares, ya que por su naturaleza esta forma de control tiene como límite los hechos. Así se ha resuelto anteriormente (roles 450 y 465).

\section{Examen de constitucionalidad de decretos supremos debe ejercer- se en términos amplios}

Al facultarse a esta Magistratura para decidir sobre la constitucionalidad de los decretos supremos se le ha entregado una prerrogativa en términos amplios. El control se extiende tanto a los decretos que se dicten en ejercicio de la potestad reglamentaria autónoma como de ejecución, sean estos de efectos generales o particulares, y respecto a la causa que lo hace procedente, la Carta señala que tiene competencia para conocer de la cuestión "cualquiera sea el vicio invocado". 
Esta amplitud se condice con la exigencia que se impone al Estado en el cumplimiento de su misión servicial: que actúe "con pleno respeto a los derechos y garantías que esta Constitución establece".

No cabe, por consiguiente, excluir en el control de un precepto legal o reglamentario, la consideración de los efectos que puedan producir en los derechos fundamentales y que todo órgano del Estado está obligado a respetar y promover. Así se ha hecho en tres requerimientos en que estaba en juego el derecho a la vida ${ }^{1}$.

Cuando ha sido necesario ponderar una cuestión de hecho de la que depende dar por acreditada la vulneración de un derecho fundamental, el Tribunal no ha rehusado hacerlo.

\section{Control de constitucionalidad exige considerar eventuales efectos nocivos del fármaco en el derecho a la vida}

Se estima improcedente que el Tribunal evalúe los efectos de un fármaco que ya cuenta con registro sanitario, los cuales ya fueron verificados por el órgano competente. Ocurre, sin embargo, que esta $\mathrm{Ma}$ gistratura debe resolver la constitucionalidad de las normas contenidas en un acto administrativo, esto es, de normas infraconstitucionales que obligan a los organismos, instituciones y funcionarios que integran la Red Asistencial del Sistema Nacional de Servicios de Salud a aconsejar, prescribir y distribuir gratuitamente un fármaco, para cuya decisión no se puede dejar de considerar los eventuales efectos nocivos que en el derecho a la vida de las personas, desde su concepción, pueda producir su ingesta.

\section{La formulación de juicios de mérito es improcedente}

Efectivamente, a esta Magistratura no le compete decidir sobre ello y limitará su pronunciamiento a las cuestiones de constitucionalidad alegadas, como reiteradamente lo ha decidido. De este modo no entrará a examinar el mérito de las normas, pero sí las cuestiones de constitucionalidad promovidas. Si así no lo hiciere incumpliría la obligación de ejercer

1 En el proyecto de ley sobre trasplantes de órganos (Rol No 220) el Tribunal, luego de analizar los informes científicos acompańados, llegó a la conclusión de que la abolición total e irreversible de todas las funciones encefálicas constituye la muerte real, definitiva, unívoca e inequívoca del ser humano. Respecto del Decreto Supremo que introdujo la restricción de circulación a los vehículos catalíticos ( $R o l$ No 325) señaló que, atendida la situación ambiental existente, resulta necesaria para proteger la salud de la población. Por último, en relación al Decreto Supremo que establecía la norma de emisión para molibdeno y sulfatos de efluentes descargados desde tranques de relave al estero Carén (Rol No 577) razonó para desestimarlo que no se había acreditado la existencia de una situación o riesgo que pusiera en peligro el derecho a la vida y a la integridad física y psíquica. 
sus atribuciones, la que deriva del principio de inexcusabilidad y, además, en cuanto órgano del Estado, del deber que le asiste de respetar y promover los derechos esenciales que emanan de la naturaleza humana ${ }^{2}$.

\section{Derechos de los padres a educar a sus hijos no está vulnerado}

Se impugna la consejería a adolescentes que se da en el marco de confidencialidad sin consentimiento ni conocimiento de los padres, por vulnerar el derecho y el deber preferente de estos a educar a sus hijos.

De las normas constitucionales y orgánicas constitucionales se infiere que los padres intervienen tanto en la enseñanza formal de sus hijos escogiendo el establecimiento de enseńanza que prefieran para ellos conforme al ideario educativo que sustente su acción, como en la enseńanza informal de la que son uno de sus agentes principales.

Los padres tienen tanto el derecho preferente como el deber de educar a sus hijos, y corresponde al Estado otorgar especial protección al ejercicio de ese derecho.

En cuanto derecho de los padres es una facultad de obrar frente a órganos del Estado, instituciones, grupos y personas que pretendieran dirigir, orientar o llevar a cabo la educación de sus hijos, que se traduce en la elección del establecimiento en que tendrá lugar la enseñanza formal $y$ en las acciones educativas que realice el núcleo familiar en la enseñanza informal de niños y adolescentes.

$Y$ en cuanto deber constitucional se traduce en obligaciones de hacer, las que existen tanto en la enseñanza formal en que los padres han de colaborar con la acción educativa del establecimiento que eligieron para sus hijos, como en la enseńanza informal en que no pueden eludir la responsabilidad educativa que les incumbe.

La educación sexual es un aspecto de la educación en el que cobran relevancia especial los valores en que se fundamenta, y de ella no puede excluirse a los padres de los menores que la reciban, lo que sería inconstitucional.

Entre otros, en los Roles Nos. 608, 609, 610, 611 y 612 (acumulados), razonó que su competencia limita en el mérito de la norma en que supuestamente incide el vicio de inconstitucionalidad, pues esta Magistratura, al velar por la aplicación efectiva del principio de supremacía constitucional, debe, igualmente, cumplir con los principios establecidos por la Constitución (arts. $6^{\circ}$ y $7^{\circ}$ )". Agregó que "la Carta Fundamental establece órganos legislativos, administrativos y jurisdiccionales, y cuando estos últimos controlan la constitucionalidad de los actos de los primeros, no pueden invadir su campo propio, por lo tanto, les está vedado entrar a calificar el mérito, oportunidad o conveniencia de la norma impugnada, debiendo limitar su pronunciamiento a la conformidad o disconformidad del acto de cuyo control se trate, con los principios, valores y normas constitucionales". 
El Decreto Supremo no vulnera el derecho de los padres a educar a sus hijos ni les impide el cumplimiento del deber que les incumbe, al establecer la consejería a adolescentes en un marco de confidencialidad sin consentimiento ni conocimiento de ellos. En efecto, no les impide escoger el establecimiento educativo de sus hijas adolescentes ni transmitirles conocimientos y valores sobre la vida sexual.

\section{Requerimiento no explica de qué forma se vulneraría igualdad ante la ley}

Al solicitar la declaración de inconstitucionalidad de la totalidad o parte del Decreto Supremo, se afirma que uno de los vicios de que adolecería la anticoncepción de emergencia, es la infracción a la garantía de igualdad ante la ley, la que no se especifica y hasta donde resulta comprensible, parece fundarse en una desigualdad entre embriones que no explica suficientemente. Sin embargo, el escrito por el cual subsana sus defectos, presentado para corregir su falta de claridad y precisión, que permitió acogerlo a tramitación, no impugna norma alguna por infringir el derecho a la igualdad ante la ley, por lo que esta Magistratura carece de competencia específica para conocer de la materia y no emitirá pronunciamiento sobre el punto.

\section{Existe un conflicto de relevancia jurídica que debe ser dirimido}

La impugnación se centra en la inconstitucionalidad de que adolecerían ciertos métodos de anticoncepción hormonal, "de emergencia", referidos a la llamada "píldora del día después", ya sea a través de la entrega de una sola pastilla (progestina pura generalmente levonorgestrel de 0,75 $\mathrm{mg}$ ), o a través de la combinación de píldoras (método "Yuzpe"), por adolecer ambos de un efecto abortivo contrario a la Constitución, planteándose así un conflicto que debe ser dirimido por esta Magistratura para verificar si un órgano público -el administrador- ha incurrido en una infracción a valores, principios o reglas contenidos en la Carta a través de la dictación de un decreto supremo cuyos efectos producirían resultados contrarios a ella ${ }^{3}$.

En efecto, aquel "se produce cuando un órgano público o una persona, con su acción u omisión, generan como resultado la infracción valórica, formal o sustancial, de preceptos o principios contenidos en la Constitución". "Surge cuando los efectos de un hecho o acto son contrarios a ella, sin que sea necesario que en todos los casos existan partes o intereses intersubjetivos en juego". "La sentencia es el medio más eficaz para resolver los conflictos constitucionales y recuperar como efecto derivado la plena vigencia de la suprema norma violentada". Сolombo Campbel., J. (2006) El debido proceso constitucional. Santiago: Cuadernos del Tribunal Constitucional No 32 . 
Las características que rodean a este conflicto - de relevancia jurídica- son las que fundamentan la competencia asignada al Tribunal, que al resolverlo fortalece la plena vigencia del Estado de Derecho, tanto en su aspecto material como formal, considerando que la declaración de inconstitucionalidad de las normas no busca sustituir la forma de gobierno, pero sí procura, mediante el control jurisdiccional, asegurar el balance y la cooperación entre los poderes.

\section{Interpretación definitiva, inapelable e integral de la Constitución}

Desde 1970 el ordenamiento ha previsto un sistema de solución de conflictos constitucionales -reforzado en 2005- que está radicado en este Tribunal, al que corresponde la interpretación definitiva e inapelable de la Constitución, que debe desarrollarse en forma integral, esto es, considerando tanto la letra como los valores, principios y espíritu de la Carta, a fin de asegurar la vigencia efectiva de la supremacía, que es la que garantiza, en definitiva, la eficacia del Estado constitucional de Derecho y el respeto de los derechos fundamentales.

\section{Control de la supremacía constitucional exige ponderar hechos relacionados con la ciencia y la técnica}

La naturaleza del conflicto tiene como fundamento los efectos que producen los métodos de anticoncepción hormonal objetados, no considerados en forma aislada, sino en cuanto forman parte de la norma obligatoria impugnada, lo que lo aleja de un mero control abstracto de constitucionalidad que se reduce, exclusivamente, al contraste entre una norma infraconstitucional y aquella de máxima jerarquía positiva.

La creciente complejidad de las cuestiones que actualmente deben abordar las jurisdicciones constitucionales, lleva a que en casos como estos el Tribunal deba ponderar ciertos hechos relacionados con la ciencia o con la técnica, a fin de arribar a una solución que efectivamente asegure la supremacía material y formal de la Carta.

\section{Principio de inexcusabilidad}

No obstante la falta de consenso científico el Tribunal se encuentra compelido a resolver el conflicto, para lo cual resulta indispensable precisar en qué consiste la "anticoncepción hormonal de emergencia".

Los antecedentes coinciden en que supone la utilización de métodos que tienden a prevenir el embarazo, después de producida una relación sexual, y cuando no se han utilizado métodos anticonceptivos previos o el utilizado ha presentado alguna falla. Pero entre la "anticoncepción" y "contracepción" de emergencia existen diferencias, lo que reviste importancia, 
pues si los efectos de la anticoncepción pueden llegar a afectar al "embrión”, ello resultará determinante para el juicio de constitucionalidad ${ }^{4}$.

Existen posiciones encontradas acerca de los efectos de la anticoncepción de emergencia cuando ellos se relacionan con impedir la implantación. La evidencia que provee la ciencia médica es contradictoria y no aparece rodeada de elementos que convenzan definitivamente en orden a que ella no afectará la vida de un ser humano concebido, aunque no nacido, que merece plena protección constitucional.

Se debe recordar un criterio hermenéutico de carácter general: "las palabras técnicas de toda ciencia o arte se tomarán en el sentido que les den los que profesan la misma ciencia o arte, a menos que aparezca claramente que se han tomado en sentido diverso" (art. 21 C. Civil). Así, el intérprete está obligado a entender las palabras técnicas en el sentido que los especialistas que cultivan la respectiva ciencia o arte las entienden, sin que pueda atribuírsele otro significado. Ocurre, sin embargo, que los antecedentes que obran en autos no solo no contribuyen a clarificar el sentido del término "implantación", sino, además, estos sentenciadores han podido constatar visiones del todo contrapuestas.

Para algunos se refiere solo a una "célula" que, surgida como consecuencia de la fecundación y en la medida que se desarrolle, puede llegar a constituir un embrión, para otros, lo que se implanta es más que una célula: es un ser humano plenamente identificable y distinguible de sus padres por su conformación cromosómica y que ha surgido, precisamente, como consecuencia de la fecundación.

La diferencia de posiciones entre especialistas ha sido constatada por otros tribunales que han debido resolver esta materia 5 .

Para estos sentenciadores la falta de consenso entre expertos y, por ende, la falta de certeza acerca de una de las posibles consecuencias de la anticoncepción de emergencia, como es que impida la implantación de

El doctor Fernando Orrego Vicuña sostuvo que un "anticonceptivo" supone "un procedimiento que impida la concepción: la unión del ovocito con el espermio", en tanto que un "contraceptivo" "comprende lo anterior como los procedimientos que tiendan a impedir el desarrollo del embrión". El Informe de la Universidad Católica afirma que "el término anticoncepción de emergencia es inexacto e induce a error, ya que estos pueden actuar no solo como anticonceptivos sino que también interfiriendo con la implantación del embrión, es decir provocando un aborto precoz".

5 Así, en la causa caratulada "AGES contra Instituto de Salud Pública", la Corte de Apelaciones de Santiago (10 diciembre 2004) puso de relieve "la encrucijada actual de no existir verdad científica indiscutida en relación a los efectos del fármaco en análisis". La Corte Suprema (28 noviembre 2005) al rechazar los recursos de casación en la forma y en el fondo confirmó que "no es cuestión demostrada en este juicio la cualidad abortiva del fármaco aludido ni tampoco que su utilización pudiera provocar, en grado de certeza, un peligro de la vida del que está por nacer (...)”. En sentencia de amparo constitucional (23 mayo 2006) la Tercera Sala del Tribunal Constitucional del Ecuador dejó constancia que: "(..) esta Sala, consciente de todo el debate científico y social, no puede aseverar que la concepción se produce desde la fecundación del óvulo, pero tampoco puede estar seguro (sic) de lo contrario". 
un ser humano con las características propias de tal, resulta evidente, y ello tiene un impacto determinante, pues incide, ni más ni menos, que en el momento mismo del comienzo de la vida de un ser humano, lo que el ordenamiento constitucional busca cautelar de manera preferente.

La evidencia científica allegada no permite excluir, en términos categóricos y concluyentes, la posibilidad de que la "píldora del día después" en cualquiera de sus versiones, no sea capaz de afectar la implantación de un óvulo fecundado o de un embrión o, en definitiva, de un ser humano, en los términos que se han definido por la propia ciencia médica.

\section{Alcance del vocablo "personas"; sujeto de derechos y titular de derechos}

En relación al encabezado del artículo 19, don José María Eyzaguirre hizo saber que: "(...) pareció mucho más lógico usar la palabra 'personas', en primer lugar, porque el concepto de 'habitantes' (Carta de 1925), como lo dijo el señor Silva Bascuñán, circunscribe el ámbito espacial de la garantía, en materias que muchas veces no lo deben estar, porque trascienden el espacio, y hoy día el Estado no solo actúa dentro de su territorio físico, sino que también, en vista del sinnúmero de relaciones internacionales, fuera de él. Además pareció lógico usar la palabra 'personas', que es el verdadero sujeto de derecho y que tiene una connotación filosófica mucho más clara que el término 'habitantes', por cuanto la persona es un ser que está dotado de mucho mayor trascendencia que el habitante, lo que se puede aplicar incluso a quienes no son personas, siendo este el sentido que tuvo presente la Subcomisión" 6 .

Se pone de relieve así la calidad de "sujeto de derecho" y, por ende, titular de derechos, que caracteriza a toda persona a quien se aseguran los derechos reconocidos en la Carta, como también aquellos esenciales que emanan de la naturaleza humana garantizados en tratados internacionales ${ }^{7}$.

El estatuto constitucional se construye sobre la base del reconocimiento de la persona como sujeto de derecho.

(Sesión $\mathrm{N}^{\circ} 156,7$ octubre 1975, p. 9).

El profesor Patricio Zapata ha sostenido que "en nuestro derecho positivo solo son sujetos de derecho las personas, sean estas naturales o jurídicas (art. 54 C. Civil). Es sujeto o persona todo ser capaz de adquirir derechos o contraer obligaciones. La calidad de persona supone la capacidad -o al menos la potencia- de querer y obrar, cualidades que solo se manifiestan en el hombre (persona natural) o en las asociaciones humanas (personas jurídicas)".

El profesor Silva Bascuńán, "a propósito de la palabra "personas" señala "las personas jurídicas que todavía no están constituidas como tales están amparadas desde la partida, antes de su reconocimiento, por el derecho de asociación. De manera que si, de cualquier forma, se actuare arbitrariamente para negar la personalidad jurídica desde el inicio a esas personas naturales o jurídicas que quieran dar nacimiento a otra persona jurídica, el derecho de asociación quedaría atropellado". Sesión N ${ }^{\circ} 156,7$ octubre 1975, p. 11. 
La propia Carta se ha encargado de caracterizar a la persona en una visión humanista que enfatiza que ella es sujeto y no objeto del derecho. Así, sus atributos básicos se encuentran en el artículo $1^{\circ}$ que afirma que "las personas nacen libres e iguales en dignidad y derechos", de lo que se sigue que el ser humano, independientemente de su edad, sexo o condición particular, es acreedor siempre a un trato de respeto.

Sin perjuicio de las características de seres dignos, libres e iguales, que singularizan a toda persona, debe considerarse la sociabilidad que le es inherente y que se expresa en "la familia es el núcleo fundamental de la sociedad" y que "el Estado reconoce y ampara a los grupos intermedios...".

Una última característica de la persona que fluye de los valores y principios recogidos en el artículo $1^{\circ}$, es que está dotada de materia y espíritu, pues al definir el bien común o fin del Estado, se le impone a este, no solo el deber de estar al servicio de la persona humana, sino además "contribuir a crear las condiciones sociales que permitan a todos y a cada uno de los integrantes de la comunidad nacional su mayor realización espiritual y material posible, con pleno respeto a los derechos y garantías que esta Constitución establece".

\section{Concepción iusnaturalista en materia de derechos}

Cuando la Carta "asegura" determinados derechos a las "personas", solo está reconociendo atributos propios de su naturaleza; que no es la Constitución la que ha creado esos derechos sino que, simplemente, se ha limitado a reconocerlos, a regular su ejercicio y a garantizarlos a través de mecanismos jurídicos adecuados para no tornar ilusoria su protección. De allí que el propio ejercicio del Poder Constituyente, en cuanto expresión de la soberanía, reconoce como límite el "respeto a los derechos esenciales que emanan de la naturaleza humana”.

Al mismo tiempo, el mandato imperativo de "asegurar" tales derechos importa: a) que solo puede asegurarse lo que existe previamente; b) que la condición de seguridad que el Constituyente desea brindar a los derechos que reconoce supone hacer cesar cualquier transgresión o vulneración que, más allá de los propios límites previstos por la Carta, puedan experimentar tales derechos, como también impedir la amenaza o peligro inminente que pueda afectarlos; y c) que deben diseńarse e implementarse todos los mecanismos necesarios para brindar efectiva protección, tanto a la titularidad de tales derechos cuanto a su ejercicio.

Para el constitucionalismo contemporáneo los derechos fundamentales -que se aseguran a todas las personas- poseen una doble naturaleza que justifica su rol central en las Cartas y en los instrumentos internacionales. Por un lado constituyen facultades que se reconocen a su titular, dando lugar a su dimensión "subjetiva", y por otro dan unidad y sentido a todo el ordenamiento jurídico, dimensión "objetiva". 


\section{El ser concebido, aunque no nacido, puede ser ubicado dentro de la categoría de "personas" a que alude la Carta}

Si así se concluye pueden serle atribuidos los derechos que ella asegura.

La doctrina constitucional chilena se ha inclinado mayoritariamente por sostener, a diferencia de lo sustentado por profesores de otras disciplinas del derecho, que la protección constitucional de la persona se inicia desde el momento mismo de la concepción ${ }^{8}$.

\section{El embrión es persona y, por tanto, sujeto de derecho}

Si al momento de la concepción surge un individuo que cuenta con toda la información genética necesaria para su desarrollo, constituyéndose en un ser distinto y distinguible completamente de su padre y de su madre, estamos frente a una persona en cuanto sujeto de derecho.

La singularidad que posee el embrión, desde la concepción, permite observarlo ya como un ser único e irrepetible que se hace acreedor, desde ese mismo momento, a la protección del derecho y que no podría simplemente ser subsumido en otra entidad, ni menos manipulado, sin afectar la dignidad sustancial de la que ya goza en cuanto persona.

La jurisprudencia de otros tribunales se ha expresado en similares términos?

Vivanco Martínez, A. (2001) "El derecho a la vida y la discusión acerca del concepto de persona humana en el ámbito constitucional". Revista Chilena de Derecho. Vol. 28, ํ2, pp. 474 y 477. Cea Egaña, J.L. (2004) Derecho Constitucional Chileno, Tomo II, Santiago: Ediciones Universidad Católica de Chile, p. 47. Informe en Derecho de Alejandro Silva Bascunán y Francisco Cumplido Cereceda que sostiene: "los principios básicos del constitucionalismo y de la hermenéutica de los Derechos Humanos, los avances en la genética, el tenor literal del precepto del artículo $19 \mathrm{~N}^{\circ} 1$, los principios inspiradores de nuestra legislación nacional plasmados en el Código Civil (art. (sic) 55, 74, 75 y 76), y lo dispuesto en el art. 4 de la Convención Americana de Derechos Humanos, y artículo 1 de la Ley $\mathrm{N}^{\circ}$ 20.120 , llevan a concluir que el nasciturus desde su concepción no solo es un ser humano, sino que además, en tal carácter, es titular del derecho a la vida desde ese mismo momento, y que el Estado tiene el deber de protegerlo". Finalmente Nogueira Alcalá, Humberto (2007) Derechos fundamentales y garantías constitucionales. Tomo I. Santiago: Editorial Librotecnia, p. 313.

9 La Corte Suprema de Costa Rica sostuvo que "en cuanto ha sido concebida, una persona es una persona y estamos ante un ser vivo, con derecho a ser protegido por el órdenamiento jurídico". Sentencia, 15 marzo 2000.

La Corte Suprema de Argentina seńaló: Este Tribunal ha reafirmado el pleno derecho a la vida desde la concepción. También ha dicho que el hombre es eje y centro de todo el sistema jurídico y en tanto fin en sí mismo -más allá de su naturaleza trascendente-su persona es inviolable y constituye un valor fundamental con respecto al cual los restantes valores tienen siempre carácter instrumental. Sentencia, 5 marzo 2000. 


\section{Protección constitucional de la persona, a partir del momento de la concepción}

Ello está plenamente reafirmado desde que se discutió la reforma que cambió la expresión "hombres" por "personas" (art. 10).

En el Senado se dejó constancia que: "El nasciturus, desde la concepción, es persona en el sentido constitucional del término, y por ende es titular del derecho a la vida" 10 .

Para el Constituyente el embrión o el nasciturus es persona desde el momento de la concepción, porque la Convención Americana-que forma parte del ordenamiento jurídico chileno- señala que "Toda persona tiene derecho a que se respete su vida. Este derecho estará protegido por la ley y en general, a partir del momento de la concepción. Nadie puede ser privado de la vida arbitrariamente", resaltándose así que todo ser humano tiene derecho a la vida sin que nadie pueda privarlo de ella arbitrariamente.

\section{El derecho a la vida es el derecho fundante de todos los demás}

Sin vida, difícilmente tiene sentido referirse a otros derechos fundamentales ${ }^{11}$.

Se asegura a toda persona -incluyendo al nasciturus - el derecho a mantener la vida y a conservarla frente a los demás hombres. Si se quiere, "es el derecho a que nadie nos la quite, y a que no pueda suprimirla ni cercenarla su propio sujeto".

El Constituyente aseguró el derecho a la vida y a la integridad física y psíquica de la persona, pues el derecho a conservar la vida como un todo incluye la posibilidad de exigir que ella no sea menoscabada, física o psíquicamente. Se trata de dos derechos que, aunque diferentes, se relacionan y complementan de manera inescindible.

10 La constancia se originó a la solicitud del senador Carlos Bombal que planteó: "Con la enmienda propuesta que sustituye la expresión "Los hombres" por "Las personas", alguna doctrina podría pretender sostener que solo es persona y, por ello, sujeto de derecho el individuo que ha nacido, con lo cual la criatura concebida y no nacida no tendría la calidad de persona". Así, solicitó formalmente a la Mesa que "Recabe el acuerdo con el objeto de hacer constar, para la historia fidedigna, que, ante el hipotético caso de que este proyecto se convierta en norma constitucional, jamás se podrá desprender de él que, en conformidad a nuestro ordenamiento fundamental, se es persona y, por ello, sujeto de derecho a partir del nacimiento, pues este asunto ya fue zanjado al protegerse la vida del que está por nacer.

11 El Comité de Derechos Humanos de la ONU ha señalado, el derecho a la vida es "el derecho supremo respecto del cual no se autoriza suspensión alguna, ni siquiera en situaciones que pongan en peligro la vida de la nación". "El derecho a la vida es el más esencial de estos derechos".

La Comisión Interamericana de Derechos Humanos reitera que "el derecho a la vida es ampliamente reconocido como el derecho supremo del ser humano y conditio sine qua non para el goce de todos los demás derechos". 


\section{La Constitución confía al legislador las modalidades concretas de protección de la vida del que está por nacer, entendiendo que se trata de un ser existente inserto en la concepción de persona y sujeto de derecho}

Así se advierte del debate que tuvo lugar en la CENC donde Jorge Ovalle propuso establecer que la ley protege la vida del "ser" que está por nacer; "para él, es importante dejar constancia de que se trata de un ser existente, siendo esta la razón de su sugerencia”. Jaime Guzmán agregó que esta referencia es estrictamente necesaria "porque cree que es enteramente distinto de todos los demás derechos", ya que en lo demás "se trata de personas que están vivas y, en cambio, en este se trata de una persona que se quiere preservar que esté viva, lo que es muy distinto". En el mismo sentido, Alejandro Silva Bascuñán señaló que no concibe "que se quite un derecho a quien no ha tenido oportunidad de defenderse o que no ha tenido oportunidad de realizar ningún acto".

De ese debate puede concluirse que la intención del Constituyente fue confiar al legislador las modalidades concretas de protección de la vida del que está por nacer, en el entendido que se trata de un ser existente e inserto en la concepción de persona, en cuanto sujeto de derecho.

Este mandato al legislador importa la protección de un derecho y no solo del bien jurídico de la vida, distinción que no es menor. En efecto, si solo se hubiese protegido la vida, en cuanto bien jurídico, bastaría que el legislador hubiese consagrado mecanismos que aseguraran al nasciturus la viabilidad de la vida intrauterina hasta el nacimiento. Sin embargo, el legislador -interpretando correctamente el mandato constitucional- ha establecido acciones e instrumentos concretos destinados a que el nasciturus opte a la protección de sus derechos como cualquier otro titular. Así se desprende de diversas disposiciones legales ${ }^{12}$.

12 Del Código Civil (arts. 75, 181 y 243), del Código Orgánico de Tribunales (art. 369) y del Código Sanitario (art. 16), de la Ley $\mathrm{N}^{\circ} 14.908$, sobre Abandono de Familia y Pago de Pensiones Alimenticias, (modificada Leyes $\mathrm{N}^{\circ}$ s. 19.741 y 20.152), de la Ley sobre Impuesto a la Renta (Decreto Ley $\mathrm{N}^{\circ} 824$, de 1974 , art. $7^{\circ}$ ) y del artículo $1^{\circ}$ de la Ley $\mathrm{N}^{\circ} 20.120$, sobre la Investigación Científica en el Ser Humano, su Genoma y Prohíbe la Clonación Humana, que señala:

"Esta ley tiene por finalidad proteger la vida de los seres humanos, desde el momento de la concepción, su integridad física y psíquica, así como su diversidad e identidad genética, en relación con la investigación científica biomédica y sus aplicaciones clínicas". 
La jurisprudencia también se ha pronunciado en torno a la protección de la "persona" que está por nacer, en cuanto sujeto de derecho, en forma congruente con la preceptiva constitucional ${ }^{13,14}$.

\section{El Tribunal debe pronunciarse no obstante las discrepancias cien- tíficas}

Es un principio procesal básico que "el juez falla conforme al mérito del proceso" y la evidencia presentada solo refleja la existencia de una disparidad profunda de opiniones, sobre todo en el mundo científico.

Tales discrepancias, sin embargo, no pueden llevar a esta Magistratura a eludir un pronunciamiento: ello no solo importaría renunciar al ejercicio de sus atribuciones esenciales de cautelar los derechos fundamentales y de defender la supremacía constitucional, sino además significaría vulnerar el deber de inexcusabilidad que pesa sobre todo tribunal.

\section{Ante una duda razonable se debe dar aplicación al principio pro homine o favor libertatis}

Si se acoge la tesis de que solo existiría un ser humano, una persona, desde la implantación del embrión en el endometrio, impidiendo las píldoras del día después tal implantación, no habría atentado contra la vida de una "persona" en los términos que la Carta lo entiende. Por el contrario, si se sigue la tesis de quienes sostienen -como además lo entendió el Constituyente- que la vida comienza con la concepción, esto por la unión del óvulo y del espermatozoide, un eventual efecto de las píldoras del día después que impidiese la implantación de un ser vivo -o de una persona- se transformaría en un aborto del todo contrario a la protección constitucional de la vida del que está por nacer que la Constitución ha impuesto al legislador y que como derecho fundamental todos los órganos del Estado tienen la obligación de respetar y promover.

De esta forma, la equivalencia que pudiera existir entre las posiciones de los especialistas que han aportado elementos de convicción a este proceso se rompe, pues una de ellas produce un resultado inconstitucional, mientras que la otra no.

13 Así, la Corte Suprema en Sentencia de 30 de agosto de 2001 señaló: "el que está por nacer cualquiera sea la etapa de su desarrollo prenatal, pues la norma constitucional no distingue, tiene derecho a la vida, es decir, tiene derecho a nacer y a constituirse en persona con todos los atributos que el ordenamiento jurídico le reconoce, sin que a su respecto opere ninguna discriminación".

14 La Contraloría ha dictaminado que "el nonato debe ser considerado como persona, de modo, que si la vida de un ser en gestación ha sido interrumpida en las circunstancias previstas en la ley No 19.123, este debe ser estimado como causante de los beneficios que esta normativa regula". Dictamen 25.403, 21 agosto 1995. 
Por tanto, ante una duda razonable, puesto que no se puede cuestionar el raciocinio de quienes son expertos en la ciencia médica, estos jueces acuden a aquellos criterios hermenéuticos desarrollados por la teoría de los derechos fundamentales; al principio "pro homine" o "favor libertatis"15.

\section{Debe preferirse la interpretación que favorece el derecho a la vida}

De modo que si puede ocasionar la interrupción de la vida del embrión al impedirle implantarse en el endometrio femenino, se debe privilegiar aquella interpretación que favorezca el derecho de "la persona" a la vida frente a cualquiera otra que suponga anularlo. Razonar de otra manera importaría desconocer la dignidad sustancial de toda persona, que supone que los derechos de que es titular son, incluso, anteriores al ordenamiento jurídico positivo, pues son manifestaciones de su propia naturaleza. Asimismo, llevaría a desconocer que las políticas que la autoridad va desarrollando en pro de la consecución del bien común de todos y cada uno de los miembros de la comunidad nacional tienen, como necesario límite, el respeto a los derechos que la Constitución asegura.

Un razonamiento diferente importaría afectar el principio del Estado de Derecho, que obliga a los órganos del Estado someter su acción a la Constitución y a las normas dictadas conforme a ella, porque la sola duda razonable de los expertos de que su aplicación pueda llegar a afectar el derecho a la vida del nasciturus, obliga al juez constitucional a aplicar el principio "favor persona" o "pro homine" en forma consecuente con el deber impuesto al Estado de estar al "servicio de la persona humana" y de limitar el ejercicio de la soberanía en función del respeto irrestricto del derecho más esencial derivado de la propia naturaleza humana, de la que el nasciturus participa en plenitud.

\section{Inconstitucionalidad derivada}

El imperativo de proteger y promover el derecho a la vida, conduce a declarar inconstitucionales las Normas Nacionales sobre Regulación de la Fertilidad, en la parte contenida en el acápite 3.3 de la Sección C, "Anticoncepción Hormonal de Emergencia”, pero deberá estimarse inconstitucional también, por derivación, la sección D referida a la "Anticoncepción en Poblaciones Específicas", acápite 1, en la parte que se refiere a la "anticoncepción de emergencia", porque siguiendo la jurisprudencia de norma más favorable a la persona humana”. Opinión Consultiva 5, 1985. 
este Tribunal, resuelto "que un determinado artículo es inconstitucional, igualmente lo son aquellas normas del mismo que se encuentran tan ligadas a aquel, que por sí solas carezcan de sentido, se tornen inoperantes o, dada la íntima conexión entre sí, se pueda presumir razonablemente que los órganos colegisladores no las hubieren aprobado" (STC, 28 julio 1998, Rol No 276).

\section{Declaración pronunciada en sede abstracta de constitucionalidad tiene un efecto erga omnes}

No escapa a la consideración de esta Magistratura el impacto que una declaración de inconstitucionalidad con efectos generales está llamada a producir en una materia que, sin perjuicio de las consideraciones jurídicas tiene también connotaciones afectivas que son plenamente respetables. No obstante, es preciso recordar que "los preceptos de esta Constitución obligan tanto a los titulares o integrantes de dichos órganos como a toda persona, institución o grupo", por lo que tanto los órganos del Estado, como toda persona, institución o grupo se encuentran en el imperativo de acatar la decisión del Tribunal, que ha ejercido la tarea que el propio Constituyente le ha confiado de velar por la supremacía, sustantiva y formal, de la Carta Fundamental.

\section{Voto CONCURRENTE DEL Ministro Mario FERNÁNDEZ}

\section{La vida tiene preeminencia sobre la libertad y la seguridad; es el supuesto de todos los derechos y es inherente a la dignidad humana}

El derecho a la vida es inherente al constitucionalismo moderno y, por ende, a la democracia y al Estado de Derecho. Es el principal entre los derechos fundamentales. Ocupa el primer lugar en la Declaración Universal: "Todo individuo tiene derecho a la vida, a la libertad y a la seguridad de la persona" (art.3). En esta norma el titular es el individuo, no la persona, aun cuando esta segunda expresión se encuentra repetidamente usada en el mismo cuerpo jurídico en referencia a prácticamente todos los otros derechos.

La vida tiene preeminencia sobre la libertad y la seguridad en la redacción del precepto indicado, no solo por la ubicación, sino porque la doctrina establece dependencias entre tales derechos: "La vida es un supuesto para que la libertad pueda vivirse. De suyo es (la vida) un estado de existencia libre" (Cathrin Correll).

La relación entre la vida y la libertad ha sido no solo objeto de las controversias relativas al aborto, sino que ha dado sustento para explica- 
ciones de alto nivel en la teoría jurídica: "La vida humana tiene en abstracto un peso superior a la libertad general de hacer y de no hacer lo que se quiera. Entonces, la importancia que tenga la protección de la vida en una situación determinada puede determinarse a la vez según el peso abstracto de la vida y según su riesgo en el caso concreto" (Robert Alexy).

El derecho a la vida es inherente a la dignidad humana. Esta abarca la dignidad de la persona, pero la excede, es propiedad de la civilización y no de convicción religiosa, política o cultural. Se trata de un rasgo esencial e indiscutible de un estadio de civilización al cual la humanidad ha llegado.

Su dimensión jurídica se encuentra en la consagración positiva de los derechos fundamentales, entre ellos, el derecho a la vida.

Su reconocimiento en la Constitución respondió a la cultura jurídica y política imperante en la época de su redacción, expresada tanto en los acuerdos verificados en la CENC como en el Grupo de Estudios Constitucionales, observándose clara coincidencia entre aquellas posiciones. La pervivencia casi total de la formulación de los derechos fundamentales en la Carta de 1980 después de su gran reforma (2005) revela un cierto consenso entre los actores políticos y la sociedad acerca de la riqueza dogmática del catálogo de derechos.

La Constitución no solo es una norma plenamente vigente, sino además goza de legitimidad político-jurídica.

\section{El derecho a la vida está reconocido en toda su extensión y con- tenido}

La estructura de todo el artículo 19 así lo revela.

Con la errada afirmación que no siendo el que está por nacer persona, podría afirmarse también que el inciso "se prohíbe la aplicación de todo apremio ilegítimo" no afectaría a las personas, o no solo a ellas, pues así no está expresamente señalado en el texto.

\section{El precepto "la ley protege la vida del que está por nacer" perte- nece a la esfera del derecho a la vida, al grupo de derechos funda- mentales denominados como de status negativus}

El verbo rector es proteger; el ámbito protegido es la vida; el sujeto activo es la ley; y el sujeto pasivo es el que está por nacer ${ }^{16}$.

16 "Se trata de una protección que pretende una omisión del estado en afectaciones ilegítimas en la esfera del individuo y que también permite combatir afectaciones o intervenciones ya ejecutadas" (Joaquín Brage C): "En su significado negativo, los derechos fundamentales se ajustan a la defensa contra intervenciones: una intervención (así es como se define) presupone siempre un hacer del Estado. Por lo tanto, la defensa contra la intervención solo puede 
Si se combina proteger con el verbo rector asegurar, se está ante un doble fortalecimiento de la protección que la Constitución otorga a la vida del que está por nacer: "asegura proteger".

La doble protección descrita cobra especial sentido considerando la indefensión en que se encuentra el que está por nacer. La negación de su carácter de persona y, por lo tanto, de su titularidad de derechos conduciría al despojo de toda defensa jurídica de quien no tiene ninguna defensa material ni física.

El precepto constitucional se ve confrontado con el deber de protección de una categoría de ser viviente respaldado magramente por un estatus jurídico residual otorgado por la moral o por leyes específicas.

La doctrina moderna, especialmente el derecho penal, habla, incluso, de excluir del status personae a seres. Así, dado que en determinadas situaciones personales o sociales la existencia del concebido no deseado genera el impulso de desembarazarse de él, lo que encontraría cobertura jurídica si el no nacido carece de titularidad, el solo peligro de que la protección establecida en el precepto constitucional no se brinde, exige protegerla como lo ordena la Constitución. La ley ya la protege en términos concluyentes (art. 75 C. Civil y art. 119 Código Sanitario).

\section{La vida del que está por nacer protegida en nuestra Constitución excede los límites que el debate jurídico intenta imponerle}

En la base del derecho está la vida. Esa que el Diccionario define como: "fuerza o actividad interna sustancial, mediante la que obra el ser que la posee". Toda esa vida, de toda la naturaleza, le importa al derecho y a los tribunales. A toda esa vida, seres humanos, animales y vegetales, le llega la letra y la voz del derecho. Pero no hay entre esas dimensiones de la vida ninguna que necesite más del cuidado del derecho que el que está por nacer.

\section{VOTO CONCURRENTE DEL MINISTRO MARCELO VENEGAS}

\section{La utilización de la anticoncepción de emergencia representa una posibilidad cierta de causar aborto}

El Ejecutivo sostiene que solo existe embarazo y es propio hablar de protección constitucional y de aborto, después de producida la implantación, lo que implica sostener que interceptar y abatir un embrión humano

entrar en acción allí donde el Estado ha actuado aun cuando no estuviera autorizado por razón de un derecho fundamental" (Dieter Grimm). 
en el lapso que media entre la concepción y su implantación en el útero materno, es jurídicamente irrelevante, tanto constitucional como penalmente, salvo que una ley expresa le conceda alguna protección especial. Se afirma que "en ningún caso" la anticoncepción de emergencia produce efectos abortivos.

La sentencia no acoge esa tesis y demuestra que la protección constitucional de la vida que está por nacer comienza desde el momento mismo de la concepción.

El alcance restringido que se le atribuye a la protección penal de la vida del que está por nacer es incorrecto, al reconocer como sujeto pasivo del delito de aborto únicamente al embrión o feto anidado, pues en este punto la opinión dista de ser unánime.

Los expedientes administrativos de los registros denegados y autorizados de los productos farmacéuticos que constituyen la anticoncepción de emergencia revelan que los propios laboratorios que los fabrican o importan informan al cuerpo médico que el producto "es un progestágeno, que inhibe la implantación del óvulo en el endometrio", el cual, aunque no se conoce su mecanismo de acción exacto "... puede producir cambios en el endometrio que dificultan la anidación...", lo que basta no solo para fundar una duda razonable sobre sus efectos abortivos, sino para formar la convicción de que es algo bastante real que la anticoncepción de emergencia puede interceptar el óvulo ya fecundado e impedir su implantación, destruyendo una o muchas vidas humanas en su etapa más temprana.

Otras naciones han concluido que bajo sus constituciones es posible despenalizar el aborto, en mayor o menor medida e incluso completamente, reconociendo en este último caso a las mujeres un derecho al aborto más o menos amplio y, consecuentemente, excluyendo o restringiendo la protección constitucional de la vida del no nacido durante toda la gestación o en parte de ella. Hay sistemas jurídicos que castigan cualquier forma de aborto; otros que no castigan ninguna por considerar que el derecho de la mujer a decidir su maternidad es absoluto y, por último los que han diseñado fórmulas diversas para resolver eventuales conflictos de intereses entre los derechos de la mujer y los del hijo no nacido que lleva en su vientre, fundamentándolas en consideraciones de distinta naturaleza.

\section{El conflicto sobre la anticoncepción de emergencia pone en vi- gencia la cuestión del aborto en Chile}

Si la Constitución lo excluye absolutamente o si el legislador puede despenalizarlo en ciertos casos, o si en la Constitución puede encontrar fundamento un derecho absoluto de las mujeres a abortar por el simple deseo de hacerlo o con que límites el legislador podría autorizarlo. 


\section{Los antecedentes de la norma son claros y evidencian dos posturas en la CENC: los partidarios de prohibir expresamente cualquier conducta abortiva (Guzmán y Silva Bascuńán) y aquellos que no son partidarios de referirse al tema (Ovalle) o derechamente entregarlo a la regulación del legislador (Ortúzar y Evans) ${ }^{17,18}$.}

17 En la CENC (sesión 84, 4 noviembre 1974) el señor Guzmán señaló que "siempre ha echado de menos la consagración del derecho a la vida como el primero de todos los derechos", agregando, lo que "sí queda excluido de suyo -y habría que mencionarlo- es el aborto. El derecho a la vida evidentemente excluye y hace ilícito el aborto". En la sesión 87 (14 noviembre 1974) Ovalle indica que "en cuanto al aborto, no es partidario de él, pero no cree que deba ser materia constitucional. El aborto está condenado indirectamente al consagrar el derecho a la vida". Silva Bascunán "se inclina mucho más a mantener silencio y que se desprendiera la condenación del aborto de la filosofía que ya se colocó como básica en el capítulo primero, y se guarde silencio en este otro aspecto". Guzmán enfatiza su oposición agregando que "lo que le mueve a rechazar el aborto es la dignidad del ser humano, lo mismo que lo motiva a rechazar el homicidio (...) el aborto no es más que una forma de homicidio y en su concepto este no es legítimo, porque atenta contra la dignidad del ser humano, del cual otro ser humano no puede disponer".

18 En la sesión 88 José Luis Cea expresa; "el aborto es un crimen y por lo tanto un atentado contra el primero y más fundamental de los derechos del hombre: el derecho a la vida; salvo el caso del aborto terapéutico -que podría ser perfectamente reglamentado en la legislación penal- no es lícito, no es legal, ni mucho menos constitucional; lo lógico es que el constituyente consagre explícitamente el derecho a la vida, como el primero y más fundamental de los derechos del hombre, y reservar al legislador penal -tal vez con el criterio que la moderna técnica penal seńale, introduciendo alguna modificación a la normativa penal- la reglamentación del aborto terapéutico y la proscripción del aborto no terapéutico...". Ortúzar manifiesta su acuerdo de "dejar entregada a la ley la protección de la vida del que está por nacer, autorizando, en forma flexible, el aborto terapéutico cuando estén en pugna el derecho de la madre con el derecho del hijo".

En la sesión 90 ( 25 noviembre 1974), se analiza cuál será el campo de acción que se le reconoce al legislador. Silva Bascuńán precisa que "entiende que cuando se está estableciendo en la Constitución que debe protegerse la vida del que está por nacer, de ninguna manera se concede libertad al legislador para determinar, soberana y arbitrariamente, de qué manera va a protegerla, de modo que no le parece que pueda argumentarse que el legislador quedó libre para hacer lo que desea en materia de protección de los derechos del que está por nacer". Ortúzar expresa que "en realidad lo que no se quiso hacer en la Constitución fue ni hacer permisible el aborto terapéutico ni condenarlo, y si no se ha hecho permisible ni se ha condenado es porque se le ha entregado al legislador la protección de la vida del que está por nacer, tal como ocurre hoy día en la disposición del Código Civil, y estima que nadie podría afirmar que el aborto terapéutico constituye delito, porque no está consignado como tal. Entiende que se ha querido hacer una diferencia entre el precepto que consagra el derecho a la vida y la disposición que entrega al legislador el deber de proteger la vida del que está por nacer. En el primero se trata de consagrar en forma absoluta el derecho a la vida. En el segundo se desea dejar cierta elasticidad para que el legislador, en determinados casos, por ejemplo, el aborto terapéutico, no considere constitutivo de delito el hecho del aborto. A su juicio la única solución lógica sería esta, pues no significa imponer las convicciones morales y religiosas de los miembros de la Comisión a la comunidad".

Silva Bascuńán manifiesta que "considera que es un avance establecer no solo el precepto de protección del derecho a la vida, sino también la protección de la vida del que está por nacer porque eso será un buen argumento para que el legislador no abra la posibilidad a la legalización excesiva del aborto. Estima que es evidente que ahí no hay una prohibición directa y absoluta, pero existe una disposición implícita que se fortalece si acaso se incluye en la Constitución dicha frase, y le parece que queda más sólida la condensación implícita de 
La doctrina nacional es nutrida y variada en relación con el campo de acción que la Constitución abre al legislador en materia de aborto. Las tesis van desde la licitud del aborto terapéutico hasta su antijuridicidad o, en su caso, inexistencia.

Estando actualmente penalizada toda forma de aborto (Código Penal y Código Sanitario), de prosperar una modificación legal que pretendiera abrir espacios de licitud a la práctica de alguna clase de aborto, será porque el legislador ha tenido la prudencia de ponderar que incursiona en un campo que el constituyente quiso deliberadamente hacerle restrictivo y exigente, y habrá limitado su iniciativa a casos tan calificados y justificados que podrán conciliarse con el contexto valórico y normativo de la Constitución.

todo abuso del legislador si se coloca esa frase que si no se incluye. Declara que es partidario de establecer dicha expresión, porque el legislador tendrá, en esta forma, mucha inclinación por sostener esta posición defensiva de la vida del que está por nacer".

Evans precisa "que no tiene inconveniente en que se conserve la frase si se deja constancia que ello se hace porque esa frase implica un mandato flexible para no sancionar penalmente formas de aborto terapéutico en que haya mediado una decisión responsable del padre o del facultativo".

Ovalle precisa "que para él esta norma es flexible, pero esa flexibilidad no la entiende tan limitada como lo aprecian los señores Silva Bascuñán y Evans y solo desea señalar que entiende el legislador deberá tratar con acopio de antecedentes, informes técnicos y estudios concretos que el constituyente no puede, necesariamente, tener a la vista, el problema del aborto, pero no podrá hacerlo con la liberalidad con que se ha abordado este problema en los países nórdicos, porque es deseo del constituyente que lo considere en forma restringida".

Ortúzar expresa, al referirse al aborto terapéutico que es la forma principal que, probablemente, podrá considerar el legislador, pero no se atrevería a afirmar que es la única. Si el día de mańana ocurriera una violación se inclinaría a autorizar ese caso de aborto".

Al concluir Ortúzar señaló que "considera que se ha avanzado bastante, porque, se está estableciendo ya una pauta en la Constitución, y por norma general, se está condenando el aborto, y no podría dictarse una ley que lo hiciera permisible, pero el legislador determinará si hay casos tan calificados, como el del aborto terapéutico, principalmente, que puedan no ser constitutivos de delitos.

En sesión 407 (7 de agosto de 1978) al debatirse el Informe Final, el cual incluía una referencia al aborto, Guzmán se opuso a ella y también a un párrafo que señalaba: "De este modo el legislador con mayor flexibilidad, podrá contemplar los casos en que el aborto debe tener carácter delictual. Una condenación absoluta en el texto constitucional habría necesariamente comprendido los casos de aborto terapéutico y otros en que la concepción puede haber sido la consecuencia de acciones violentas no consentidas, situaciones que desde un punto de vista moral o social pueden ser apreciadas de diferentes maneras, según sean las creencias o principios religiosos de quienes las juzguen".

En definitiva, el Informe Final precisa: "La Comisión estimó que la consagración del derecho a la vida implica necesariamente la protección del que está por nacer, porque, si bien la existencia legal de la persona comienza con el nacimiento, no es menos cierto que ya en la vida intrauterina tiene una existencia real, que debe serle reconocida. Se constitucionaliza así un principio que, por lo demás, contempla nuestro Código Civil desde su dictación.

La Comisión estimó, sin embargo, conveniente dejar entregada al legislador la protección de la vida del que está por nacer".

En el Consejo de Estado (sesión $N^{\circ} 58,12$ diciembre 1978) el consejero Juvenal Hernández "hace presente sus dudas en cuanto a las ventajas de trasladar a la Constitución una norma del derecho privado, como es la protección del que está por nacer. Teme que esta innovación pueda dar lugar a debates, interpretaciones desaconsejables". 
Comparto la posición de Enrique Evans de que la Constitución confiere un mandato flexible pero restrictivo al legislador: "lo que ni la ley ni la autoridad podrían autorizar o tolerar, sin infringir la Constitución, es la práctica del aborto común".

\section{La anticoncepción de emergencia es inconciliable con la Consti- tución}

La única justificación para su establecimiento es "disminuir los embarazos no deseados y sus consecuencias"; y basta para tener acceso a ellas "no desear" el embarazo o, lo que es lo mismo, "desear" utilizarlo.

La Constitución puede tolerar casos muy calificados de aborto, siempre que lo disponga justificadamente el legislador y se trate de situaciones conciliables con el respeto a la dignidad humana y los derechos fundamentales, pero no se divisa que la Constitución permita que por un acto administrativo se haga lo que se prohíbe a la ley, como autorizar abortos que pueden justificarse únicamente en el "deseo" de una mujer de no embarazarse después de una relación sexual. Más aún si se pretende instaurar un sistema público destinado a promover y facilitar los medios para su práctica generalizada y masiva, y sin más justificación que la voluntad de la mujer.

Si se imponen altas exigencias para que una ley pueda autorizar casos muy calificados y justificados de aborto, la Constitución no permite a la Administración autorizarlos autónomamente para ser practicados por el simple deseo de la madre.

La tesis del Ejecutivo de que la vida del que está por nacer adquiere relevancia jurídica y puede ser víctima de aborto solo una vez que se ha implantado en el útero materno, puede ser muy respetable y hasta llegar a imponerse en el futuro, pero no tiene hoy la capacidad de interpretar la Constitución de forma obligatoria ni, menos, de modificarla.

En una comunidad democrática la trascendencia de un tema tan sensible para la sociedad con un alto impacto en las creencias y preferencias ideológicas y éticas de las familias y de la juventud, y que irremisiblemente producirá un cambio en la forma de vida a la que estamos acostumbrados, demanda ser discutido en el Congreso Nacional.

\section{VOTO DISIDENTE DEL MINISTRO JUAN COLOMBO}

\section{Está precluida la oportunidad para impugnar las políticas en ma- teria de salud reproductiva aplicadas por más de medio siglo}

Se solicita declarar inconstitucional el Decreto Supremo No 48, "por cuanto fija, aprueba y hace suyo" las "Normas Nacionales sobre Regulación de la Fertilidad", dictado en cumplimiento de la sentencia rol 
No 591, que declaró inconstitucional (en voto de mayoría y por motivos de forma) la Resolución del Ministerio de Salud No 184, de 2006, que aprobó dicho cuerpo normativo.

En escrito de "cumplimiento de lo ordenado" los requirentes refieren su impugnación al uso de los métodos anticonceptivos denominados "píldora del día después" y "dispositivo intrauterino", y solicitan declarar la inconstitucionalidad de "todo o parte" del decreto supremo.

Esta Magistratura limita acertadamente su decisión a lo solicitado en relación a la denominada "píldora del día después", en atención a que los dispositivos intrauterinos se encuentran regulados por cuerpos normativos que no caben dentro del ámbito del decreto impugnado, por lo cual se encuentra precluida la oportunidad para someterlos ahora a control de constitucionalidad. Por esta vía no corresponde cuestionar la constitucionalidad ni pronunciarse acerca de las políticas gubernamentales en materia de salud reproductiva implementadas por alrededor de medio siglo, las cuales, además, se encuentran plenamente vigentes y en aplicación.

\section{La titularidad de los derechos corresponde a las personas}

La Constitución está construida para organizar jurídicamente al Estado y garantizar los derechos individuales. En relación a estos, reconoce el hecho jurídico del nacimiento, al disponer que "las personas nacen libres e iguales en dignidad y derechos"; que "el Estado está al servicio de la persona humana"; y asegura "el derecho a la vida y a la integridad física y psíquica de la persona”, señalando más adelante que encomienda al legislador la protección de la vida que está por nacer.

Los derechos fundamentales asegurados por la Constitución se refieren a la protección de los atributos que las personas tienen, amparándose su igualdad ante la ley, la igual protección en el ejercicio de sus derechos, el respeto de su vida privada, su libertad y seguridad personal, su propiedad, entre muchos otros, sin que quepa margen de que su titularidad corresponde a personas, que son reconocidas como sujetos de derechos.

\section{El Constituyente garantiza los derechos de la persona humana nacida}

No estableció el inicio de la protección jurídica de la vida del que está por nacer, sin perjuicio de utilizar la fórmula de enviar un mensaje al legislador para implementar a futuro su protección.

El Código Civil se refiere a las personas y las clasifica (naturales y jurídicas). En relación a las personas naturales regula dos hechos jurídicos: el nacimiento y la muerte, bajo el acertado concepto de "principio y fin de la existencia de las personas". Define a las personas naturales como todo individuo de la especie humana, cualquiera que sea su edad, sexo, estirpe 
o condición, disponiendo que "la existencia legal de toda persona principia al nacer, esto es, al separarse completamente de su madre", y establece que "la criatura que muere en el vientre materno, o que perece antes de estar completamente separada de su madre, o que no haya sobrevivido a la separación un momento siquiera, se reputará no haber existido jamás".

\section{El constituyente delega en el legislador precisar el instante a par- tir del cual se debe proteger la vida por nacer}

De lo anterior se colige que la protección de la vida por nacer parte del supuesto de que ella existe y que la Constitución delega en el legislador precisar el instante y las condiciones en que dicha protección debe comenzar a operar.

Frente a la certeza de la vida del que está por nacer, se le otorga al órgano jurisdiccional la facultad de dictar las providencias que le parezcan convenientes para proteger la existencia del no nacido, siempre que de algún modo peligrare.

Hasta ahora, la legislación ha dado cumplimiento a la norma constitucional $^{19}$.

El momento a partir del cual se comete el delito de aborto no está establecido en el Código Penal, y es un punto de discusión (Garrido; Politoff, Matus y Ramírez, exigen un estado de embarazo consolidado). Más allá de la dogmática jurídica, la figura de aborto exige la interrupción de un embarazo, que de por sí ha de estar consolidado para poder ser objeto de protección penal, consolidación que solo se podría dar por establecida a partir del día 14 de la concepción, según lo señala un estudio de Fernando Zegers. Para concluir entonces la protección a partir del momento de la concepción derivada del acto sexual, no resultan conducentes ninguna de las normas legales ni constitucionales, ya que para ello se requiere una certeza que supere las concepciones clásicas acerca del inicio de la vida, lo que genera un conflicto científico más que jurídico, pues ni la Constitución ni la ley precisan el instante del inicio de la vida humana.

\section{Determinación del inicio y término de la vida es una materia en- tregada a la ciencia médica, ajena a las convicciones personales}

Al alegar un "efecto abortivo" los requirentes están aludiendo a un hecho que, de ser efectivo, se encontraría contemplado como típico por el Código Penal, lo cual hace mucho más relevante el cumplimiento del onus probandi por su parte, sobre todo si el aborto está penado y se trata

19 El artículo 119 del Código Sanitario dispone: "No podrá ejecutarse ninguna acción cuyo fin sea provocar un aborto", lo que se sanciona como delito en el Código Penal. 
de un acto de autoridad (decreto supremo que promovería la distribución de medicamentos de efectos abortivos).

El inicio exacto de la vida humana, y en determinadas condiciones el momento de la muerte, es un tema no consensuado. La moral, las ciencias y las distintas profesiones de fe plantean sus tesis, por ende, es una problemática que no se encuentra ni puede estar resuelta completamente por el derecho. Al enmarcarse entonces en el plano del ejercicio de la libertad de conciencia que la propia Carta reconoce y también en la investigación científica, no cabría imponer, con efecto de cosa juzgada, una determinada concepción excluyente de las otras y de paso zanjar, en sede jurisdiccional, un debate científico.

El Estado debe velar por la protección de la vida de las personas naturales y lo hace directamente a través de su poder público para prevenir las acciones de terceros que pudiesen poner en riesgo tal derecho; al reconocer el derecho a la protección de su salud con el objeto de que se preserven sus vidas y, en el caso de la vida por nacer, a través del mandato al legislador que lo concreta.

La protección de la vida desde el punto de vista de la salud está en manos de la ciencia médica, y en ese contexto la determinación del inicio y el término de la vida humana, mediante el conocimiento y la investigación, es labor de los profesionales que la ejercen.

\section{El inicio de la vida humana es un hecho incierto y no consensuado}

Del mérito del proceso no se desprende que exista consenso médico acerca de la oportunidad precisa en que se inicia la vida humana; y la Carta no otorga más elementos de juicio ni orientaciones suficientes, de tal forma que ello no puede determinarse en una sentencia que les dé aplicación. Es la medicina, la ciencia, la que debe precisar los momentos del nacimiento y la muerte de la vida humana, oportunidades fácticas que no pueden ser determinadas por medio de la decisión de un tribunal y que escapan al control de la jurisdicción.

La muerte sí está regulada por el Derecho, que exige la intervención de un médico que la constate para así dar efectos legales al término de su vida. En cambio, en este proceso no consta que algún médico pueda emitir un certificado profesional acerca de la existencia de antecedentes que demuestren un hecho incierto y no consensuado para la ciencia que profesan: que se ha iniciado la existencia de una vida humana.

\section{Naturaleza del conflicto planteado no está regulado por el sistema jurídico}

Debemos reflexionar cuál es la real y profunda naturaleza del conflicto planteado para decidir si nos enfrentamos a uno de intereses de rele- 
vancia jurídico constitucional que justifique emitir un pronunciamiento, porque si concluimos que es de naturaleza médico, ético o religioso, este Tribunal no puede resolverlo en ejercicio de su jurisdicción ${ }^{20}$.

A esta solo le corresponde resolver conflictos de derecho, definidos como aquellos en los cuales el parámetro de juzgamiento esté constituido por normas jurídicas, en este caso de rango constitucional, y los requirentes sustentan su pretensión, además, en normas de orden moral y en algunas corrientes de la ciencia médica, por lo que el conflicto sometido a esta Magistratura no se encuentra regulado por el sistema jurídico, siendo un tema que se desarrolla dentro del marco de la libertad de conciencia y de creencias. Los hechos así lo demuestran.

\section{Normas impugnadas no establecen la obligación de utilizar el método anticonceptivo. Tampoco le entregan potestades al Esta- do para imponer su uso compulsivo}

Se confiere una posibilidad de uso del mismo, acompańado de consejería para las adolescentes que la soliciten, en el marco de la libertad de opción informada, lo que se ampara por diferentes garantías constitucionales (libertad personal, de conciencia y respeto por la vida íntima de las personas).

\section{El acto administrativo impugnado se funda en el orden legal y no procede entrar a calificar la constitucionalidad de la preceptiva legal habilitante}

Si el conflicto surge por la dictación de un decreto es necesario precisar el concepto de acto administrativo y tener presente lo dispuesto en la Ley Orgánica del Ministerio de Salud, es en ese ámbito que debe decidirse si al dictarlo se actuó dentro del marco constitucional o si se excedió, ya que los actos administrativos deben ajustarse al sistema jurídico que los autoriza, y en lo específico a sus normas habilitantes (arts. $6^{\circ}$ y $7^{\circ}$ ), lo cual si no se cumple implica una vulneración de la Constitución y la ley. legal ${ }^{21}$.

El Ministerio de Salud solo se ha limitado a actuar dentro del marco

La jurisdicción, como función pública, es conceptualizada como el poder-deber que tienen los tribunales para conocer y resolver por medio del proceso y con efecto de cosa juzgada los conflictos de relevancia jurídica.

21 Si el acto administrativo sometido a control se apartara de las normas legales habilitantes conforme a las cuales se dicta, se produce la desvinculación de uno y otra dejando de constituir un todo concordante y sistemático para transformarse en partes de una relación leyacto administrativo que se contrastan y se repudian por exceder el acto del marco legal que lo hace nacer, violándose, en ese caso, la Carta, al dictarse un acto que excede la normativa habilitante. En esta hipótesis el acto administrativo puede ser objetado, ya que su enjuicia- 
Si se examina el contenido de las fuentes legales más relevantes que habrían facultado la dictación del acto administrativo cuestionado, con el propósito de establecer si el mismo contiene o no la correspondiente contrapartida de habilitación legal, previa y suficiente que exige la Carta en relación con el dominio legal, por una parte, y la potestad reglamentaria del Presidente que lo habilite para ejecutarlas, por la otra, debe concluirse que se encuentran en armonía y concordancia, que es un mero acto de ejecución que no contraría la Constitución, quedando de manifiesto entonces que si la impugnación de constitucionalidad de este proceso sobrevive a dicho análisis, lo que en realidad se estaría impugnando es el conjunto de preceptos legales que habilitan a la autoridad competente para dictar el acto impugnado.

Si bien la reforma 2005 confirió a este Tribunal competencia para controlar la constitucionalidad de leyes vigentes, esta Magistratura solo puede ejercerla en los casos y formas establecidas por la Constitución y las leyes. Por ello no puede, en sede de control de actos administrativos, luego de concluirse la concordancia entre el acto impugnado y su normativa legal habilitante, entrar a calificar la constitucionalidad de la preceptiva legal que rodea al acto impugnado, pues implicaría una extralimitación de funciones y una intromisión en un acto legislativo ${ }^{22}$.

\section{El decreto impugnado no afecta intereses de titularidad de los re- quirentes}

Si bajo sus convicciones morales y religiosas la píldora del día después pudiere ser objetable, nadie los obliga a verse sometidos al uso de la misma, a lo que se suma que en ejercicio de la misma libertad de creencias, otros grupos o personas pueden encontrarse en la legítima situación de no tener objeciones de conciencia al respecto, sin que aquellos puedan desconocer tal libertad e imponer a toda la comunidad los efectos de sus convicciones íntimas.

\section{Carga de la prueba corresponde a los requirentes; presunción de constitucionalidad}

Es un principio general de derecho universalmente aceptado la carga de probar los hechos en un proceso y de acreditar los derechos invocados a quien lo alega, y en este proceso resulta de cargo de los requirentes acreditar las supuestas infracciones que denuncian al derecho a la vida y

miento se efectuaría sin que ello importe una intromisión del Tribunal en un acto legislativo que no ha sido llamado a controlar de conformidad a sus atribuciones. 
a otras normas constitucionales, lo que no han hecho, generándose como efecto inmediato que no cabe dar lugar a su solicitud.

Este Tribunal reiteradamente ha seguido el criterio de la conformidad a la Constitución de las normas controladas, también denominado "presunción de constitucionalidad": las normas emanadas de los poderes públicos, en tanto expresión de la soberanía del pueblo, valor fundamental de un régimen republicano, se entienden ajustadas a la Constitución mientras no se acredite lo contrario, lo que no ha ocurrido en el proceso.

$\mathrm{La}$ alegación de que esta Magistratura, en tanto órgano del Estado, tendría un supuesto "deber de abstención" que debiera llevar a prohibir la distribución mientras no se acredite que la píldora no es abortiva, es inadmisible, en términos procesales, al invertir la carga de la prueba y desconocer la presunción de constitucionalidad, sin perjuicio de que se demanda la prueba de un hecho negativo, lo que resulta imposible.

$\mathrm{Si}$ se alegó que era abortiva y que atenta en contra del derecho a la vida debió acreditarse, condictio sine qua non para la procedencia del requerimiento.

\section{Voto disidente del MinisTro HeRnÁN VodanoviC}

\section{Cuestión debatida}

En este proceso se discute sobre: 1) La existencia, rango y entidad de los derechos del embrión preimplantacional; y 2) El eventual conflicto entre un interés constitucionalmente protegido y otros derechos fundamentales, como los de orden reproductivo y sexual.

El nasciturus -sostengo- no es titular de los derechos fundamentales reconocidos por la Constitución, que la Carta no prohíbe el aborto, que los mencionados derechos reproductivos tienen reconocimiento constitucional y, por último, que el interés preponderante -si existiere un conflicto de valores de relevancia constitucional- recae en los derechos fundamentales de la mujer.

\section{Es inconstitucional toda creencia o doctrina que imponga sus propios valores de forma excluyente}

Las constituciones deben ser entendidas hoy como normas abiertas, lo que permite la diversidad cultural, de creencias y de expresión. El principio rector es la libertad de las personas y el libre desarrollo de la personalidad, resultando ajena al régimen constitucional toda creencia o doctrina que busque la imposición de su pensamiento o valores de forma excluyente respecto de las otras. Un fallo no debe tener como sustento o referencia concepciones religiosas o morales singulares y no puede ser usa- 
do para imponerse a los otros miembros de la comunidad. La libertad en un régimen republicano consiste en la libertad como ausencia de dominación. Según este concepto mínimo y básico de libertad, su dimensión negativa sería la capacidad de hacer lo que se desea sin interferencias de otros, especialmente de la autoridad. La libertad se traduce en la no interferencia de la autoridad estatal en materias que están fuera de la órbita de la gestión de los asuntos públicos, respeto por la vida privada y la inviolabilidad del hogar. Si el inicio de la vida y su protección es un tema influido por las concepciones religiosas, metafísicas y morales de las personas, los órganos del Estado no pueden imponer opciones sin lesionar dichas libertades, privando a las personas del derecho a optar por los métodos anticonceptivos que deseen, en imposición de una determinada moral.

\section{La titularidad de los derechos fundamentales está radicada en la persona o en grupos determinables de personas}

Esos derechos subjetivos, en virtud de los cuales se exige una determinada conducta a los poderes públicos, conforman una esfera de autonomía de la persona, garantía frente al poder estatal que no puede ser interferida.

\section{Derechos y garantías; diferencias y alcances}

Los derechos, en cuanto valores sustantivos y autónomos, emanados de la dignidad del ser humano, deben ser diferenciados claramente de las garantías que, en tanto instituciones jurídicas de carácter adjetivo, técnicas o herramientas, procuran el aseguramiento de los derechos. Como institutos adjetivos y accesorios al derecho garantizado, las garantías se diferencian del mismo. El derecho es propio de la persona y la garantía es una parte del ordenamiento, un enunciado normativo con una función específica, que no siempre se traducirá en una dimensión subjetiva como la ya enunciada. Nuestra Constitución recoge el principio de titularidad de los derechos en la persona, es decir, en ella se consagra sin duda alguna la dimensión subjetiva de los derechos.

\section{Es persona el ser humano ya nacido}

Para constatar si se produce la infracción constitucional respecto del derecho a la vida ha de estarse en presencia de un derecho fundamental, cuya titularidad y ejercicio corresponda a un ser humano determinado como persona, derecho que, además, debe encontrarse garantizado por instituciones apropiadas.

La normativa constitucional no enuncia concepto alguno de persona, ni menos a partir de qué momento se tiene tal estatus jurídico. La única 
norma que puede dar alguna luz al respecto contiene un reconocimiento de la dignidad humana y los valores fundamentales de libertad e igualdad que de ella derivan, a partir del nacimiento. El derecho considera persona, al ser humano ya nacido. Así, al diferenciarse existencia natural de existencia legal, y en el orden penal al no concebir el tipo de aborto como un delito contra las personas. En síntesis, claramente son distinguibles dos valores: la vida humana consolidada y plena, amparada por el derecho a la vida, por ser persona y sujeto de derecho el titular de ella, y la denominada "vida por nacer", que no está reconocida como persona, y que puede llegar a tener un cierto estatuto jurídico de protección y de titularidad de derechos eventuales, condicionados al nacimiento.

\section{La Constitución atribuye el derecho a la vida a sujetos de derecho}

Esta distinción se encuentra también en la Constitución, que atribuye el derecho a la vida a sujetos de derecho, en un momento que se fija a partir del nacimiento, y lo diferencia de la "vida por nacer", al señalar que el legislador la protegerá. Si el derecho a la vida aparece como un derecho fundamental, de carácter subjetivo y de titularidad de la persona, la protección de la vida por nacer no parece ser una garantía del derecho a la vida, pues opera en un espacio temporal en el cual no existe el derecho que sería objeto de tal garantía. Por otro lado, la vaga expresión "que está por nacer" no precisa mucho el significado de esta disposición que, al no ser garantía, es solamente un mandato al legislador. "Por nacer" puede entenderse aquello sobre lo cual existe cierto margen de predictibilidad razonable que va a nacer y se va a transformar en un ser humano al momento de concluir el parto, certeza que claramente no se tiene al momento de la concepción, ni aun en los primeros meses de gestación.

\section{La Constitución no contiene un mandato explícito y directo de protección a todo germen de vida prenatal}

El constituyente solo exhorta al legislador a proteger, dentro del margen de autonomía que este posee, aquella sobre la que efectivamente exista algún grado de certeza sobre su viabilidad.

El argumento de que la vida parte con la concepción no es susceptible de ser aceptado, por ser un fundamento de orden moral sin consenso científico y, por otro lado, porque no es parte del parámetro de control de constitucionalidad del Decreto impugnado, pues el solo hecho de la concepción no da certeza alguna de que exista "vida por nacer".

El nasciturus -que no es persona- no es titular del derecho a la vida, sino que constituye en sí mismo un interés constitucionalmente relevante para el ordenamiento jurídico. El mandato de protección revela un valor constitucional, pero no le confiere derechos subjetivos al interés protegido. 


\section{El legislador tiene libertad para interpretar un concepto altamen- te abstracto y no unívoco como es el de "vida por nacer"}

En virtud del principio de autonomía del legislador reconocido por este Tribunal, debe entenderse que "el legislador no es un ejecutor de la Constitución, sino un poder que actúa libremente en el marco de esta y esta libre actuación requiere en muchos casos (aunque no, claro, en todos) que el enunciado de esos preceptos constitucionales permita un ancho haz de interpretaciones diversas. No de interpretaciones jurídicas, sino de interpretaciones políticas, es decir, de maneras diversas de entender el texto constitucional cuyos enunciados han de construirse, por tanto, con conceptos de valor de un alto grado de abstracción". El legislador puede entonces hacer diferentes interpretaciones acerca de la norma, con mayor o menor intensidad de protección, dentro de un margen de opciones bastante amplio, a partir de conceptos altamente abstractos y no unívocos, como el de "vida por nacer", que no tiene el mismo significado para todos los sectores de la sociedad. Si se han establecido las normas pertinentes en el Código Civil y Código Penal, ellas pueden ser modificadas, en virtud del principio mencionado.

\section{Preeminencia del elemento teleológico por sobre el histórico en la interpretación constitucional}

Para fundar la interdicción constitucional del aborto, se especula con la historia del establecimiento de la norma, se invoca la trascendencia del elemento histórico, pero ella es descartada por la doctrina constitucional contemporánea, que se orienta a la búsqueda de la finalidad de la norma, situada dentro de un sistema normativo, cuya concreción dependerá de las necesidades jurídicas, a su vez condicionadas e influidas por el contexto sociopolítico y cultural de cada época. De esta suerte, las convicciones íntimas de los redactores del texto original aparecen subordinadas a la finalidad y razón de la norma, tal cual esta se entiende y aplica en las diversas circunstancias.

La CENC jamás llegó a la conclusión que se le pretende adjudicar ${ }^{23}$. que existiera consenso en torno al significado de ello. Sostuvo Jaime Guzmán sobre la base de argumentos de orden moral y religioso, que la protección era absoluta, sin excepciones, y que la madre debía tener al hijo "aunque este salga anormal, aunque no lo haya deseado, aunque sea producto de una violación o aunque de tenerlo, derive en su muerte", moción que finalmente no fue aceptada. Centrado el debate en el aborto terapéutico, Ortúzar expresó que "se está seńalando la forma principal que, probablemente, podrá considerar el legislador, pero no se atrevería a afirmar que es la única". El mismo comisionado estimó "indispensable dejar entregado al legislador la protección de la vida del ser que está por nacer, porque si la Constitución derechamente lo hiciera, estaría abocándose a un problema su- 


\section{El legislador no está obligado a penalizar el aborto}

La protección de la vida del que está por nacer es una orientación al legislador que este puede materializar de variadas formas, en los diversos ámbitos del derecho (civil, penal u otros). La ley puede prohibir el aborto sancionándolo civil y/o criminalmente; pero el legislador no está obligado a penalizar el aborto, puede incluso despenalizarlo.

Si el derecho a la vida se entiende universalmente como el derecho a no ser privado arbitrariamente de ella, y se admiten como válidas causales de justificación (legítima defensa), lo que determina el legislador, se aprecia la autonomía que se le ha reconocido a este en estas materias. No existe entonces fundamento para sostener que el aborto goza de una proscripción constitucional lo que no es dable desprender de ninguna norma.

\section{La Convención Americana de Derechos Humanos no prohíbe el aborto}

Se alude que el Pacto de San José protege el derecho a la vida "en general, a partir del momento de la concepción”, pero en los trabajos preparatorios de dicho tratado, Estados Unidos y Brasil observan que "interpretan el texto en el sentido de que deja a la discreción de los Estados Parte el contenido de la legislación a la luz de su propio desarrollo social, experiencia y factores similares". De igual manera, en las sesiones se reconoció que la frase "en general, a partir del momento de la concepción” dejaba abierta la posibilidad de que los Estados Partes en una futura Convención incluyeran en su legislación nacional "los casos más diversos de aborto", lo que fue reafirmado por la Comisión Interamericana en el caso conocido como "Baby-boy vs. Estados Unidos" (resolución 23/81, 6 marzo 1981).

\section{Libertad de la mujer para vivir o no la maternidad}

Si bien en el artículo 19 no se encuentra explícitamente recogido el derecho al "libre desarrollo de la personalidad", es posible identificar la existencia de cláusulas generales de dignidad de la persona (art. $1^{\circ}$, inciso primero, y art. $5^{\circ}$, inciso segundo) y de libre desarrollo de la personalidad

mamente conflictivo y delicado como es el del aborto", indicando que "la ventaja del texto reside precisamente en que aclara el pensamiento de la comisión, ya que de otra manera podría prestarse para interpretar que la Carta condena en cierto modo el aborto. Recuerda que cuando se discutió el punto, la mayoría llegó a la conclusión de que no podían imponerse creencias religiosas propias en una materia tan delicada y trascendente como una norma de la Constitución" (sesión 407). 
(art. $1^{\circ}$, inciso cuarto). En este último precepto aparece como elemento intrínseco, en cuanto la primacía de la persona humana, como valor fundamental, nos obliga a concluir que su libre desarrollo personal debe alcanzar la mayor realización espiritual y material posible, a cuyo cometido el Estado debe contribuir creando las condiciones sociales necesarias, con pleno respeto de los derechos y garantías constitucionales. De la misma forma, se garantiza la integridad física y síquica, la libertad personal, la libertad de creencias y el derecho a la vida privada, conjunto de derechos que atribuyen a la mujer libertad para decidir cuándo desea vivir o no la maternidad, de forma libre y consciente.

En este sentido, el uso de anticonceptivos y el derecho a disponer de la maternidad por parte de la mujer es un tema antiguo y ya zanjado en el derecho constitucional comparado.

\section{Lo dispuesto en la Convención sobre la Eliminación de todas las Formas de Discriminación contra la Mujer constituye un paráme- tro en el control de constitucionalidad}

Es precisamente en la mujer en quien recaería la obligación irrestricta de aceptar el estado de embarazo, por lo que cualquier interpretación de dicho deber que implique restringir el ejercicio de cualquier derecho fundamental por causa de dicha supuesta obligación, es contraria a dicho tratado internacional y consecuentemente se opone al artículo $5^{\circ}$ de la Constitución ${ }^{24}$.

Cualquier interpretación que menoscabe los derechos de la mujer a consecuencia del embarazo debe ser descartada, por constituir una discriminación fundada en las características sexuales de ella.

Su artículo 1 entiende por discriminación "toda distinción, exclusión o restricción basada en el sexo que tenga por objeto o por resultado menoscabar o anular el reconocimiento, goce o ejercicio por la mujer, independientemente de su estado civil, sobre la base de la igualdad del hombre y la mujer, de los derechos humanos y las libertades fundamentales en las esferas política, económica, social, cultural y civil o en cualquier otra esfera". Dicha Convención establece además que los Estados se obligan a asegurar el "acceso al material informativo específico que contribuya a asegurar la salud y el bienestar de la familia, incluida la información y el asesoramiento sobre planificación de la familia" -marco en el cual no cabe duda se encuentran las normas sobre salud reproductiva y anticoncepción de emergencia-, y que "los Estados Partes adoptarán todas las medidas apropiadas para eliminar la discriminación contra la mujer en la esfera de la atención médica a fin de asegurar, en condiciones de igualdad entre hombres y mujeres, el acceso a servicios de atención médica, inclusive los que se refieran a la planificación de la familia", y que se adoptarán todas las medidas para lograr el goce de "los mismos derechos a decidir libre y responsablemente el número de sus hijos y el intervalo entre los nacimientos y a tener acceso a la información, la educación y los medios que les permitan ejercer estos derechos". 


\section{No se está frente a un conflicto entre derechos fundamentales}

Si el nasciturus no es un sujeto que goce de titularidad de derechos fundamentales, no nos encontramos en frente de un conflicto de derechos fundamentales, sino ante un aparente conflicto entre un interés de relevancia constitucional, protegido por un mandato de acción legislativa, y un derecho fundamental. Solo podríamos hablar de un conflicto real, y no aparente, si la tensión se produjere entre dos intereses o entre dos derechos, cuyo no es el caso.

Los derechos delimitan la órbita de acción del Estado y aquella esfera de ejercicio de libertad que no puede ser interferida por el mismo, de manera tal que solo en un ámbito ajeno al ejercicio de lo que se denomina el núcleo esencial de dichos derechos podrá el Estado intervenir.

\section{Derechos reproductivos y sexuales de la mujer son derechos fun- damentales}

El Estado no puede invadir el espacio de la vida privada y de la libertad de conciencia, y sobre todo, la esfera del libre desarrollo de la personalidad, concretada específica y detalladamente en los derechos reproductivos y sexuales de la mujer, derechos fundamentales que limitan el poder del Estado y que gozan de preponderancia y mayor fuerza normativa frente al resto de los intereses constitucionales, por lo que cualquier medio utilizado en desmedro de ellos resulta contrario a la Constitución.

\section{La vida por nacer está protegida con menor intensidad}

Si el derecho a la vida admite situaciones de inexigibilidad (legítima defensa o el estado de necesidad), en las que la privación de la vida está amparada por el derecho, con mayor razón es dable concluir que la vida por nacer, protegida con menor intensidad y ponderada frente a derechos fundamentales de la mujer, admite situaciones en que sus supuestos de protección decaen, entre las cuales se encuentra, desde ya, el ejercicio legítimo de derechos fundamentales de naturaleza reproductiva, sin perjuicio de otras de fuente netamente penal, como la lex artis médica en el ejercicio legítimo de la medicina y la carencia del elemento malicia exigido por el tipo de aborto.

\section{La vida por nacer debe ser ponderada con los derechos funda- mentales de la mujer}

Aun en el caso de reconocerse el rango de derecho fundamental a la protección de la vida por nacer, la misma debe ser ponderada con los derechos fundamentales de la mujer, pues esta debe soportar el estado de 
embarazo y resulta de toda obviedad que en embarazos inviables, en situaciones de riesgo de la vida e integridad de la mujer y, en general, frente a la afectación de otros derechos fundamentales relevantes, la protección absoluta de la vida por nacer en desmedro de ellos resulta desproporcionada e incluso puede llegar a ser ineficaz.

La mujer, además de sus derechos reproductivos, goza del derecho a la integridad síquica, todo lo cual puede verse gravemente alterado por un embarazo no deseado y, aun más, por la coacción del Estado para soportarlo.

La exigibilidad de los derechos de la mujer es inmediata, concreta y definida, no ocurre lo mismo en el caso del nasciturus, por la indeterminación de su estatuto, por no ser reconocido ni reconocible como persona y, por no ser identificable persona alguna como titular de dicha protección, en términos que goce de legitimidad activa para reclamarla.

Sostener que la mujer está obligada a sacrificar el ejercicio de los derechos derivados de su dignidad como persona, por razón de la protección de la vida por nacer, es una carga de la cual deberán responder quienes estén por acoger el requerimiento y que implica justificar la poco sustentable consecuencia de que el derecho a la vida de la mujer puede llegar a ceder frente a una protección de la vida por nacer, que para ello ha de transformarse en una absoluta y supuesta obligación irrestricta de nacer.

\section{El debate ético científico acerca del inicio de la vida no corres- ponde al derecho dirimirlo}

A partir del caso Roe vs. Wade (1970) las alegaciones sobre el inicio de la vida a partir de la concepción y respecto de los alcances de la autonomía reproductiva de la mujer quedó claro para la Corte Suprema Federal en Estados Unidos: "si los médicos, los teólogos o los filósofos son incapaces de ponerse de acuerdo al respecto, los tribunales no están en condiciones de especular con la respuesta".

\section{La declaración de inconstitucionalidad acarrea efectos más noci- vos que los que produce su pervivencia}

Esta Magistratura ha declarado que "no debe desatender los efectos reales que sus decisiones pueden tener para el funcionamiento pleno de las instituciones que gobiernan el Estado de Derecho"; que el ordenamiento constitucional "es un sistema normativo, que regula poderes públicos, reconoce y ampara derechos subjetivos y fundamenta, en fin, la cohesión y equilibrio político y social", por lo que la exclusión de una norma legal es consecuencia de la ruptura de ese ordenamiento, para restablecerlo en plenitud, y si dicha finalidad no se logra con la expulsión del precepto 
legal porque ello puede acarrear efectos aún más nocivos que los que produce su pervivencia debe evitarse. Si las consecuencias de la desaparición del precepto deviene en "una situación más perjudicial o negativa que la preexistente a su anulación, no resulta conveniente para el interés público y la plena vigencia del Estado de Derecho la derogación de la norma" (Rol 558). Tal es lo que ocurre con la declaración de inconstitucionalidad impetrada: perturba la formulación y ejecución de políticas públicas de salud e importa una regresión notoria en el sistema de protección de la salud reproductiva generando una situación más gravosa socialmente que su subsistencia.

\section{Es contrario a la igualdad aceptar la distribución comercial del fármaco y prohibir su entrega gratuita en el área pública}

Representa una incoherencia atribuir riesgos abortivos a medidas de anticoncepción reconocidas universalmente y prohibir la entrega gratuita a los usuarios de un fármaco en el área pública de salud pero mantener su distribución comercial con quebranto de la igualdad de derechos.

\section{VOTO DISIDENTE DE LOS MINISTROS JORGE CORREA Y FRANCISCO FERNÁNDEZ}

\section{La evidencia acumulada es insuficiente para sostener que los mé- todos anticonceptivos de emergencia impidan el desarrollo del embrión}

Los métodos de anticoncepción hormonal de emergencia no atentan en contra de la vida del que está por nacer, ni contra la dignidad humana.

La evidencia acumulada no permite sostener una duda razonable acerca de que los dos métodos de anticoncepción hormonal de emergencia impugnados sean capaces de impedir el desarrollo de un embrión humano. Es cierto que los científicos mantienen una polémica respecto de sus efectos, pero ello no es suficiente para prohibir la distribución de productos debidamente autorizados por los órganos competentes. No podría bastar que alguien manifieste una duda, seńale que existe una polémica o haga ver que los mismos productos advierten un efecto posible, quienes impugnan su distribución deben convencer, con evidencia científica, que ellos son efectivamente capaces de atentar en contra de la vida.

Lo realmente objetado es que se ordene a los profesionales del sistema público de salud aconsejar y distribuir dos específicos métodos de anticoncepción hormonal de emergencia postcoitales a base de levonorgestrel puro o de la combinación de este con etinil estradiol. 


\section{Los fármacos tienen efecto anticonceptivo y no atentan contra la vida}

La ciencia ha acreditado que los dos sistemas anticonceptivos de emergencia tienen un efecto anticonceptivo, consistente en impedir la ovulación de la mujer, requisito indispensable de la fecundación. Se encuentra asimismo postulado que los mismos retardan o dificultan la migración de los espermios hacia las trompas lo que dificulta la fecundación. $\mathrm{Ni}$ las partes, ni experto alguno han sostenido que estos efectos anticonceptivos, que consisten en evitar la fecundación, puedan atentar en contra de la vida y ser contrarios a la Constitución. Lo que los requirentes y algunos expertos sostienen, es que los fármacos tienen además de los efectos anticonceptivos ya referidos, y cuando ya no son aptos para impedir la ovulación, por haberse ella producido, la capacidad de impedir el desarrollo normal del huevo fecundado o cigoto, antes que este se anide en el cuerpo de la mujer. Existe también prueba suficiente que los sistemas de anticoncepción de emergencia no tienen efecto alguno sobre el huevo fecundado, una vez que este se ha adherido ya al cuerpo de la mujer.

\section{Debiera probarse que el fármaco impide que se anide el huevo fe- cundado}

Para acoger el requerimiento se necesita establecer que los sistemas cuestionados tienen la capacidad de impedir que se anide el huevo fecundado o de impedir por cualquier otra vía su normal desarrollo o, a lo menos, sostener que existe evidencia científica que genere una duda razonable acerca de ello. Además, que un huevo humano fecundado o cigoto es titular del derecho a la vida o que con la interrupción de su desarrollo anterior a la implantación se vulnera el mandato "la ley protege la vida del que está por nacer".

\section{Derecho a la vida o protección de la vida del que está por nacer; una o ambas reglas deben aplicarse}

Existe controversia acerca de cuál de las dos reglas, la que garantiza el derecho a la vida o la que ordena al legislador proteger la vida del que está por nacer debe aplicarse al caso y, si se estima que ambas, cómo deben armonizarse. Para unos el asunto debe examinarse de preferencia conforme a la segunda: una regla especial y diversa que establece un deber para el legislador, pero no un derecho al no nacido; para otros el no nacido es persona, titular de la garantía constitucional, por lo que tiene plena dignidad y derecho a la vida, siendo la segunda una regla especial que no debe primar, sino una mera reafirmación del derecho a la vida, de los no nacidos. Esta polémica se sustenta en el debate habido en la CENC y en 
discusiones legislativas posteriores en las que el Senado dejó constancia cómo entiende la cuestión.

También es polémico determinar el alcance de la expresión "persona"; a quien la Carta hace titular del derecho a la vida, debate que es médico, filosófico y antropológico, acerca de si el individuo de la especie humana, con identidad genética propia y diversa a la de sus padres, que la ciencia ha probado existe en los embriones, aun antes de implantarse, lo transforma en persona, titular del derecho a la vida, o si este es un concepto moral.

Tampoco es pacífica la inteligencia de la redacción descriptiva "la ley protege": obliga o limita al legislador en cuanto a lo que puede hacer con el que aún no nace o el sentido y alcance de las expresiones "vida del que está por nacer". Unos sostienen que tal deber de proteger es más débil que el derecho a la vida, por lo que la Constitución permite al legislador autorizar algunos tipos de aborto, otros que cualquier aborto atenta en contra de la vida de una persona garantida incluso para los no nacidos.

Si se concluye que la consejería, promoción y distribución de los sistemas hormonales de anticoncepción de emergencia atentan en contra del derecho a la vida, del que son titulares las personas, o en contra de la regla que ordena al legislador defender la vida del que está por nacer, es necesario aún saber si tal efecto podría justificarse en un derecho preferente de las mujeres a decidir acerca de su propia maternidad, en las finalidades públicas de salud relativas a evitar abortos clandestinos, o en el derecho preeminente de igualdad entre las mujeres ricas y pobres, dado que los métodos impugnados están disponibles en el comercio, más allá del alcance de este fallo.

Para rechazar el requerimiento no es indispensable el análisis de todas las cuestiones indicadas. Si se concluye que los anticonceptivos de emergencia no tienen la aptitud de enervar el desarrollo del embrión humano antes de su anidación, basta ello para su rechazo. Si no existen antecedentes para estimar que atentan en contra del embrión, mal podría vulnerarse el derecho a la vida de una persona, el deber de protección de la vida del que está por nacer que se impone al legislador y menos habría que contrastar aquello con otros fines constitucionales.

\section{Falta de legitimación activa de los requirentes}

Se alegó que el derecho a la vida solo puede ser limitado por ley y que se vulnera tal principio al pretender regular esta materia a través de un Decreto Supremo 25 .

25 Se afirma: a) que el Decreto impugnado regula, restringe o limita la vida del que está por nacer; b) que el de la vida es un derecho reconocido por la Carta; y c) que la Constitución 
Los requirentes no tienen legitimación activa para formular tal alegación. Ello solo puede ser planteado por la mayoría de cualquiera de las Cámaras ${ }^{26}$.

Además, acoger ese planteamiento implicaría desatender un fallo anterior. En rol 591 el Tribunal examinó una resolución ministerial que estableció exactamente el mismo contenido normativo que el Decreto ahora impugnado y la invalidó por estimar que regulaba una materia propia de un decreto supremo presidencial. No es razonable entonces que primero declare en sentencia vinculante que un determinado contenido normativo no es válido por no estar suscrito por la Presidenta como un Decreto Supremo, y cuando se cumple con ese requisito para darle validez al mismo contenido normativo se decida ahora que tampoco es válido por no estar contenido en una ley ${ }^{27}$.

\section{La libre circulación del fármaco ya está autorizada}

Se alega que el requerimiento debe ser rechazado por cuanto lo impugnado es que se ordene a los profesionales del sistema público de salud aconsejar y distribuir gratuitamente un fármaco cuya circulación se encuentra permitida por autoridad competente, acto ya cuestionado mediante una acción de nulidad de derecho público y expresamente validado por la Corte Suprema. Tal planteamiento debe ser desestimado, por cuanto lo que está autorizado y no puede volver a discutirse es la libre circulación del fármaco. Sin embargo, tal acto no valida que el Estado, a través

autoriza (con restricciones) al legislador a regular y limitar los derechos que consagra, pero tales limitaciones y regulaciones le están reservadas al legislador, por lo que el Decreto ha invadido materias propias de ley.

26 La Carta, que regula la impugnación de la constitucionalidad de un Decreto dispone que este Tribunal "solo podrá conocer de la materia a requerimiento de cualquiera de las Cámaras". Y luego ańade que "en el caso de vicios que no se refieran a decretos que excedan la potestad reglamentaria autónoma del Presidente de la República, también podrá una cuarta parte de los miembros en ejercicio deducir dicho requerimiento". En consecuencia, el Tribunal no puede entrar a conocer la alegación de que el Presidente ha excedido su potestad reglamentaria autónoma y ha invadido materias de ley, sino a requerimiento de la mayoría de cualquiera de las Cámaras.

El Tribunal razonó que "... ese acto administrativo contiene un conjunto de normas, cuyo alcance es nacional o de aplicación general a todos los destinatarios de ellas; y dotadas de carácter permanente, es decir, que no agotan o pierden vigencia por su aplicación en un caso determinado. Sin embargo, tal Resolución Exenta carece de las demás exigencias que la Constitución contempla para los decretos supremos reglamentarios, porque fue dictada por la Ministra de Salud, en circunstancias que hacerlo se halla prohibido, pues correspondía que fuese suscrita por la Presidente de la República y, además, debió ser sometida previamente al trámite de toma de razón en la Contraloría General de la República, atendida su naturaleza esencialmente reglamentaria. Habiéndose omitido estos dos requisitos esenciales para la formación válida de un reglamento, fuerza es concluir que la Resolución Exenta No 584 quebranta la Constitución, en su aspecto formal, lo que así será declarado por este Tribunal". 
del sistema público de salud, aconseje su uso y distribuya gratuitamente el producto. Es esto lo que la Magistratura está obligada a examinar.

\section{Controversia sobre un elemento fáctico no impide resolver la constitucionalidad del decreto impugnado}

Se alega que el Tribunal está llamado a resolver conflictos constitucionales que en un control abstracto deben consistir en controversias jurídicas y no en asuntos de hecho, ni menos en contiendas científicas, pues ello excede su competencia al exigir de una actividad probatoria que el procedimiento no contempla. Los hechos constituyen un límite al control abstracto de constitucionalidad.

Lo planteado exige decidir cuál es el efecto que produce el fármaco sobre el embrión gestado y no anidado, y esta es una cuestión de hecho, biológica, que incluso ocurre al interior del cuerpo de la mujer, a la que no pueden responder ni el derecho ni la moral, sino la ciencia, pues se refiere a la ocurrencia de un hecho y sus efectos -mortales o no- del fármaco sobre el embrión no anidado. Pero la existencia o no de una polémica acerca de un elemento fáctico que subyace en la decisión jurídica, no ha sido establecida ni por la Carta ni por la ley como una razón para no resolver la cuestión sometida a decisión.

Lo que se debe fallar es la cuestión de constitucionalidad de un Decreto y no hacerlo implicaría necesariamente validarlo. Si se estableciera la doctrina de que no debe emitir pronunciamiento cada vez que antes sea necesario formarse convicción acerca de un hecho, se llegaría al resultado de que serían inexpugnables los Decretos Supremos que infrinjan la Constitución si se sustentan en un hecho relevante sobre el cual el Tribunal deba convencerse para decidir la cuestión de constitucionalidad.

El Tribunal no es un órgano llamado a establecer hechos, como lo hacen los tribunales del fondo, pero ello es muy diverso a formarse una determinada convicción acerca de tales hechos como presupuesto necesario del juicio de constitucionalidad. Por el contrario, la mayoría de las resoluciones judiciales exige convencerse de hechos acerca de cuya veracidad las partes controvierten. La circunstancia de que el hecho relevante consista en un proceso biológico que se produce sobre un ser microscópico y ello ocurra al interior del cuerpo de la mujer puede hacerlo más difícil, pero no cambia en nada la necesidad de resolver acerca de la infracción constitucional alegada.

Es efectivo que las reglas procesales aplicables al control abstracto de constitucionalidad no contienen propiamente una fase de prueba. Sin embargo, la ley faculta para "decretar las medidas que estime del caso tendientes a la más adecuada sustanciación y resolución del asunto que conozca" lo que permitió recibir presentaciones escritas y abrir audiencias pública. 


\section{Se entrecruzan cuestiones morales y religiosas respecto al comien- zo de la vida y a su dignidad, pero ello no es un impedimento para resolver}

Esta es una controversia propia de la competencia del Tribunal suscitada en el orden temporal, y la polémica moral o religiosa acerca de lo que es la vida humana y su comienzo -o fin- no es, ni en la Carta, ni en la ley, razón válida para que este, ni ningún otro tribunal, se abstenga de resolver. Por el contrario, el derecho, en cuanto garantiza la vida y la dignidad de la persona, ha estado desde siempre, y cada vez más intensamente llamado a resolver cuestiones en que necesariamente debe precisarse el comienzo o el fin de la existencia humana.

\section{El mérito de las políticas públicas limita con la Constitución}

El Ejecutivo sostiene que entrar al fondo del asunto implica resolver sobre el mérito, ya que la distribución del fármaco acarrea una serie de beneficios y ante la eventual existencia de una duda acerca de los efectos de la anticoncepción de emergencia, son los órganos electos con responsabilidad política los que deben tomar la decisión. Pero no se puede pretender que la doctrina acerca de las cuestiones de mérito llegue a legitimar que las autoridades políticas puedan, a través de políticas públicas -que solo ellas formulan - infringir la Carta. Ello implicaría sostener que toda vulneración de un derecho debería ser validada, sin siquiera entrar al fondo del asunto, a condición de que existan beneficios públicos. El hecho de que las normas controladas formen parte de una política pública que se sustenta en juicios de mérito, no las inhibe del control.

\section{Requisitos que debieran cumplirse para acoger el requerimiento}

Para acoger el requerimiento sería necesario concluir: a) que los fármacos, que se ordena recomendar y distribuir, son capaces de producir la muerte de un embrión no anidado, o que, a lo menos, sobre ello existe una duda de cierta entidad; b) que el embrión humano es, aun antes de su anidación en el cuerpo de la mujer una persona y/o que es vida que está por nacer; y c) que estas formas de atentar en contra del derecho a la vida resultan injustificables.

El requisito de la letra a) es condición necesaria y primera de los siguientes: si los fármacos tienen capacidad de evitar la anidación del embrión y, con ello, interrumpir su desarrollo y darle muerte, será necesario examinar los supuestos que siguen. Si se concluye que ninguno de ellos tiene esa potencia o no existe siquiera duda suficiente de que la tengan, no tendrá sentido, determinar la entidad de la vida del embrión no implantado y su debida protección jurídica. 
Cuál es el efecto que sobre un embrión no anidado produce un fármaco al interior de una mujer es una cuestión fáctica que no puede responderse con razones éticas, morales, jurídicas o filosóficas. Los únicos criterios de verdad son empíricos. Las convicciones han de formarse sobre la base de pruebas científicas y con los antecedentes disponibles en el proceso.

Del proceso se infiere que existen algunos hechos no discutidos: a) que tanto la píldora del día después como el Yuzpe son anticonceptivos eficaces. En el sentido que tienen capacidad anticonceptiva, en cuanto dificultan la ovulación; y b) que estos fármacos no afectan la vida del embrión una vez implantado.

Lo controvertido es el efecto que producen o pueden producir sobre el embrión en la etapa previa a su anidación. Además de efectos anticonceptivos -según los requirentes- tendrían la capacidad de dar muerte al embrión antes de su implantación o de evitar su anidación o adherencia al cuerpo de la mujer, lo que impide su desarrollo y produce su muerte o, a lo menos, existe una duda razonable acerca de tal efecto. Otros afirman que no existe antecedente que permita sostener, además del efecto anticonceptivo, tenga capacidad de afectar al embrión entre que este surge, con la fecundación, y el momento de su anidación. Este último es el hecho en debate: el efecto de la píldora y del Yuzpe sobre el embrión humano o cigoto que se forma al momento de la fecundación del óvulo por el espermio y hasta antes de la implantación o anidación del mismo en el cuerpo de la mujer. Para unos los fármacos son capaces de matar al embrión o de impedir su anidación en ese lapso. Para otros tal efecto no existe. Si se acepta la primera tesis tendrá sentido seguir con las restantes cuestiones identificadas: si el embrión no anidado es persona, si su vida tiene protección constitucional, si tal protección es absoluta o mayor que los derechos de la mujer sobre su propio cuerpo, etc.

\section{Qué es lo que se debe probar y a quién le corresponde el peso de producir la prueba que sea capaz de generar convicción}

Para invalidar un Decreto Supremo por causa de inconstitucionalidad deben existir razones de peso suficientes. Tal declaración es un hecho extraordinario, no tanto por efecto de la presunción de constitucionalidad de la norma, sino por el buen funcionamiento de la democracia y del gobierno, ya que ha de partirse del supuesto de la validez de los actos de los órganos del Estado. Se debe llegar a la convicción de que los fármacos sí tienen o pueden tener efectos mortales sobre el embrión concebido y no anidado. Corresponde determinar qué debe probarse, quién debe hacerlo, y qué grado de certeza debe alcanzar la prueba.

Para determinar a quién corresponde el peso de la prueba, es necesario precisar el estado jurídico en que se encuentra el hecho debatido. El fármaco se encuentra autorizado por resolución que fue impugnada de 
nulidad de derecho público, argumentándose precisamente que tenía o podía tener efectos abortivos y la Corte Suprema rechazó tal acción, considerando que los hechos acreditados en la causa no podía modificarlos en sede de casación y que no constituían prueba suficiente de que el medicamento autorizado a circular afectare un derecho constitucional. No es posible a esta Magistratura partir entonces, sin más, del supuesto que ese fármaco es apto para interrumpir el embarazo y mortal para el embrión. Ese es un hecho que debe probarse por quienes impugnan la norma que ordena distribuir el fármaco autorizado.

Lo extraordinario, contrario a la lógica o a la forma habitual de ocurrir los hechos debe probarse, por lo que frente a un fármaco que circula con las correspondientes autorizaciones y cuyos efectos no son apreciables por los sentidos, lo extraordinario exigirá que si el mismo es dañino para la vida se deba probar.

Los requirentes han hecho ver que tratándose de la vida la conclusión debiera ser la inversa: que el hecho a probar es que el fármaco es inocuo para el embrión, que no existe riesgo de producirle la muerte. Esta afirmación es evidente, pero no señala la sede en que debe ocurrir esa prueba. Son las autoridades del Ministerio de Salud las que deben cerciorarse que el fármaco tiene propiedades benéficas y no produce efectos secundarios mortales o dańinos. Sin embargo, una vez que esas autoridades han hecho tales exámenes y lo autorizan, los terceros que aleguen que se han equivocado, deben probar el efecto dańino que alegan o, a lo menos, un cierto grado de duda acerca de ello.

Si el producto ha sido ya autorizado resultaría absurdo que este u otro tribunal lo prohibieran si esa alegación de ser mortal no viene acompańada de suficiente prueba.

\section{Certeza que cabe exigir a quien alega el efecto nocivo del fármaco}

Esta puede ir desde la capacidad de plantear una duda, hasta la certeza absoluta acerca del hecho debatido. Se argumenta que en este caso basta con que la prueba sea capaz de plantear una duda: tratándose de derechos fundamentales, y particularmente del derecho a la vida, debe siempre interpretarse la duda en pro del valor de la vida. La prueba completa del carácter abortivo exigiría experimentar con embriones para ver si se les da muerte, lo que está ética y legalmente prohibido. En este sentido, ha de concedérseles la razón y bastaría con que la prueba produzca una duda razonable, entendiendo por tal aquella que supera una mera conjetura y se apoya en evidencia que la sustenta, aunque no alcance el nivel de certeza absoluta. No basta con que una parte afirme tal efecto dańino; es necesario que acompañe prueba de la plausibilidad de lo que afirma. El valor de la vida y el carácter irreversible de la muerte hacen que sea suficiente una duda razonablemente motivada y acreditada. 
Cabría luego dilucidar de qué muerte -cierta o probable- se trata. Si la muerte es la de una persona titular del derecho a la vida, o de un ente que aún no la tiene o solo de una parte disponible del cuerpo de la mujer, pero ello solo tendría utilidad si se concluye que sí existe duda razonable acerca de tal efecto sobre el embrión. También es un problema diverso y posterior determinar qué dańos se ocasionarían en caso de restringirse el uso del fármaco potencialmente dañino; llevaría a que se produzcan más abortos clandestinos, a que haya más embarazos adolescentes no deseados entre las mujeres más pobres y a que se afecten los derechos reproductivos de las mujeres. El análisis de estas cuestiones sería necesario si existe duda razonable acerca de la capacidad del fármaco de producir la interrupción del desarrollo del embrión no anidado.

\section{La evidencia científica y no los argumentos morales deben servir para resolver}

Conforme a la evidencia acompańada es o no posible dar por acreditada una duda razonable acerca de que la píldora es capaz de evitar la implantación del embrión humano en el cuerpo de la mujer, de evitar su anidación, impedir su desarrollo y producirle la muerte de cualquier modo. Por tratarse de un hecho lo único que ha de pesar es la evidencia científica y no los argumentos jurídicos o morales.

Las partes fueron invitadas a probar sus afirmaciones con informes que indiquen con claridad y precisión los efectos que científicamente producen los métodos impugnados. Ninguna acompañó informe y sería posible sostener entonces que nada probaron sobre los efectos del fármaco por lo que no está sustentada en evidencia científica la duda razonable de que sea capaz de interferir en la vida del embrión. Sin embargo, varias entidades hicieron llegar antecedentes que de alguna forma responden a la cuestión. También en audiencias públicas autoridades científicas concurrieron a exponer ante el Tribunal y como medida para mejor resolver se analizaron los expedientes administrativos de los registros sanitarios y el expediente judicial sobre la nulidad de derecho público del fármaco Postinor-2 donde consta abundante prueba judicial. En varios estudios acompañados y en las presentaciones hechas los científicos aluden a una cierta evidencia científica, la presentan, analizan y sacan conclusiones, por lo que si hemos sostenido que solo la evidencia científica es capaz de sustentar o descartar la duda razonable debe ser ella analizada.

\section{La convicción de que los efectos producidos por el fármaco no son contrarios a la Constitución se ha adquirido con el mérito del proceso}

La evidencia científica acredita que los métodos de anticoncepción 
hormonal de emergencia son eficaces para prevenir embarazos. También que ello se debe, en todo o parte, a su capacidad de impedir la ovulación en la mujer. También existe evidencia indiciaria de que dificultan el viaje de los espermios al óvulo, aunque ello se discute y no está plenamente acreditado. Ninguno de los dos efectos antes mencionados podría considerarse contrario a la Constitución, pues no lo es prevenir la fecundación. Se discute si los fármacos podrían interferir con el embrión y es difícil una prueba cierta y definitiva por los problemas que conlleva experimentar con embriones. La experiencia con animales conduce a concluir que no hay tales efectos contrarios al desarrollo del embrión, pero se discute si tales conclusiones pueden extrapolarse a humanos. La evidencia que ha medido el efecto del levonorgestrel en otras condiciones del aparato reproductor femenino es indiciaria de que no tiene capacidad de alterar su desarrollo o anidación. Lo mismo puede decirse del Yuzpe, salvo en cuanto se emplee con dosis de levonorgestrel muy superiores a aquella que recomiendan las normas impugnadas. En consecuencia, en esta causa no se ha acreditado la existencia de una duda razonable de que ni uno ni otro de los métodos que la norma cuestionada ordena aconsejar, ni la píldora de levonorgestrel puro que ordena distribuir, son capaces de impedir la anidación de un embrión humano, de impedir su desarrollo o de darle muerte por cualquier otra vía. Esta conclusión no emana de nuestras propias convicciones morales acerca de la vida, sino de la evidencia disponible en este expediente. No negamos que pueda existir otra evidencia al margen de este proceso o que pueda producirse en el futuro, pero como jueces estamos obligados a adquirir convicción con el solo mérito del proceso.

La rotulación voluntaria u obligada del producto, si bien deja constancia de que se ha sostenido o sugerido que puede tener efecto sobre el embrión, no afirma que ello sea un hecho cierto o una duda razonable. Dejar constancia de que se ha sostenido un hecho no constituye evidencia alguna acerca de la probabilidad de su certeza.

Los expedientes administrativos acreditan que las autoridades sanitarias vienen autorizando los productos mencionados desde hace 7 ańos.

$\mathrm{Al}$ concluirse de este modo se coincide con lo resuelto por la Corte Suprema.

Habiéndose llegado a la conclusión de que la prueba no permite afirmar que la píldora tenga efectos mortales sobre el embrión, ni que sobre ello exista una duda suficientemente razonable, no resulta necesario continuar con el análisis para rechazar el requerimiento. En efecto, ya no es posible sostener que haya atentado en contra de la vida. No tendría sentido, continuar razonando acerca de la naturaleza y derechos del embrión no anidado frente a los conceptos de vida, persona, protección del que está por nacer y demás cuestiones planteadas. 